\title{
Source apportionment of submicron organic aerosols at an urban site by factor analytical modelling of aerosol mass spectra
}

\author{
V. A. Lanz ${ }^{1}$, M. R. Alfarra ${ }^{2}$, U. Baltensperger ${ }^{2}$, B. Buchmann ${ }^{1}$, C. Hueglin ${ }^{1}$, and A. S. H. Prévôt ${ }^{2}$ \\ ${ }^{1}$ Empa, Swiss Federal Laboratories for Materials Testing and Research, Laboratory for Air Pollution and Environmental \\ Technology, 8600 Duebendorf, Switzerland \\ ${ }^{2}$ PSI, Paul Scherrer Institute, Laboratory for Atmospheric Chemistry, 5232 Villigen PSI, Switzerland
}

Received: 11 September 2006 - Published in Atmos. Chem. Phys. Discuss.: 21 November 2006

Revised: 12 February 2007 - Accepted: 8 March 2007 - Published: 20 March 2007

\begin{abstract}
Submicron ambient aerosol was characterized in summer 2005 at an urban background site in Zurich, Switzerland, during a three-week measurement campaign. Highly time-resolved samples of non-refractory aerosol components were analyzed with an Aerodyne aerosol mass spectrometer (AMS). Positive matrix factorization (PMF) was used for the first time for aerosol mass spectra to identify the main components of the total organic aerosol and their sources. The PMF retrieved factors were compared to measured reference mass spectra and were correlated with tracer species of the aerosol and gas phase measurements from collocated instruments. Six factors were found to explain virtually all variance in the data and could be assigned either to sources or to aerosol components such as oxygenated organic aerosol (OOA). Our analysis suggests that at the measurement site only a small $(<10 \%)$ fraction of organic $\mathrm{PM}_{1}$ originates from freshly emitted fossil fuel combustion. Other primary sources identified to be of similar or even higher importance are charbroiling $(10-15 \%)$ and wood burning $(\sim 10 \%)$. The fraction of all identified primary sources is considered as primary organic aerosol (POA). This interpretation is supported by calculated ratios of the modelled POA and measured primary pollutants such as elemental carbon $(\mathrm{EC}), \mathrm{NO}_{\mathrm{x}}$, and $\mathrm{CO}$, which are in good agreement to literature values. A high fraction (60-69\%) of the measured organic aerosol mass is OOA which is interpreted mostly as secondary organic aerosol (SOA). This oxygenated organic aerosol can be separated into a highly aged fraction, OOA I, (40-50\%) with low volatility and a mass spectrum similar to fulvic acid, and a more volatile and probably less processed fraction, OOA II (on average 20\%). This is the first publication of a multiple component analysis technique to AMS organic spectral data and also the first report of the OOA II component.
\end{abstract}

Correspondence to: C. Hueglin

(christoph.hueglin@empa.ch)

\section{Introduction}

Ambient aerosols have several adverse effects on human health (Nel, 2005), atmospheric visibility (Horvath, 1993) and a more uncertain impact on climate forcing (Lohmann and Feichter, 2005; Kanakidou et al., 2005). The organic component of atmospheric aerosols plays an important role mainly concerning small particles: at European continental mid-latitudes, a fraction of $20-50 \%$ of the total fine aerosol mass can be attributed to organic matter (Putaud et al., 2004), and about $70 \%$ of the organic carbon mass (suburban summer) is found in particles with an aerodynamic diameter of less than $1 \mu \mathrm{m}$ (Jaffrezo et al., 2005).

Particles in the atmosphere are often divided into two categories, depending on whether they are directly emitted into the atmosphere or formed there by condensation (Fuzzi et al., 2006). Primary organic aerosol (POA) particles are generally understood to be those that are released directly from various sources. Secondary organic aerosol (SOA) is formed in the atmosphere by condensation of low vapour pressure products from the oxidation of organic gases. The quantification of different types of aerosols such as SOA and POA (or more classes if possible) is important as source identification is the first step in all mitigation activities. Furthermore, SOA and POA may be associated with different sizes, chemical composition and physical properties and thus may have different effects on climate or health.

Different classes of aerosols also exhibit different local abundances. SOA is a significant contributor to the total ambient aerosol loading on a global and regional level. The SOA contribution to organic aerosol (OA) is highly variable, according to modelling results ranging from $10 \%$ in Eastern Europe to $70 \%$ in Canada (Kanakidou et al., 2005). There is an ongoing debate about how much SOA is present in the urban boundary layer, where fresh emissions and aged air masses meet. As an example, Cabada et al. (2004) advocate

Published by Copernicus GmbH on behalf of the European Geosciences Union. 
that in Pittsburgh 35\% of the organic carbon is secondary in July, while one can deduce from another study that about $52 \%$ (calculated from Zhang et al., 2005b) of the organic aerosol mass was secondary in the same city in September. Established approaches for SOA estimates are either based on VOC emission data (e.g. Jenkin et al., 2003) or on the organic to elemental carbon (OC/EC) ratio in primary emissions (Turpin and Huntzicker, 1995; Cabada et al., 2004).

The mass spectral tracer deconvolution technique by Zhang et al. (2005a) to separate hydrocarbon-like organic aerosol (HOA) and oxygenated organic aerosol (OOA) represents the first multivariate analysis of Aerodyne aerosol mass spectrometer (AMS) data. In "Algorithm 2", measured data and vectors that initially can be described as a function of $m / z$ (mass-to-charge ratio) 44 and $m / z 57$ are alternately regressed (in version 1.1 other mass tracers are suggested along with 44 and 57: http://www.asrc.cestm.albany.edu/qz/). Marker $\mathrm{m} / \mathrm{z}$ 44 (a signal mainly from di- and poly-carboxylic acid functional groups, $\mathrm{CO}_{2}^{+}$) represents oxygenated organic aerosol components, while $m / z 57$ (butyl, $\mathrm{C}_{4} \mathrm{H}_{9}^{+}$) is a tracer for hydrocarbon-like combustion aerosol (e.g. diesel exhaust). Algorithm 2 has been proven to reconstruct measured organics very well with OOA and HOA at three urban locations. Under carefully selected conditions, OOA and HOA seem to be accurate estimates for SOA and POA, respectively (Zhang et al., 2005b; Volkamer, 2006). However, the presence of more than two active sources (likely in the urban troposphere) might limit the use of 2-factorial approaches.

In this paper, a method that allows the identification and attribution of more than two organic aerosol sources and components is presented. The apportionment of more distinctive aerosol types and source classes allows for a more accurate modelling of SOA and POA. Our approach does not rely on chemical assumptions and is based on positive matrix factorization (PMF; Paatero and Tapper, 1994; Paatero, 1997). PMF has several advantages over common versions of factor analytical approaches based on the correlation matrix as it will be discussed later. In atmospheric aerosol science, PMF has been successfully applied to deduce either sources of $\mathrm{PM}_{10}$, the mass concentration of particles with an aerodynamic diameter less than $10 \mu \mathrm{m}$ (Hedberg et al., 2005; Yuan et al., 2006) or finer fractions of particulate matter such as $\mathrm{PM}_{2.5}$ - (Polissar et al., 1998, 1999; Maykut et al., 2003; Kim et al., 2004; Kim and Hopke, 2005; Zhao and Hopke, 2006; Pekney et al., 2006) or both (Kim et al., 2003; Begum et al., 2004; Chung et al., 2005). To our knowledge, no attempts have been made so far to apply PMF on (organic) aerosol mass spectra. In most PMF studies, inorganic chemical species (mostly $\mathrm{SO}_{4}^{2-}$ and $\mathrm{NO}_{3}^{-}$) as well as trace elements were measured to describe the particulate composition of the aerosol phase. Organic components were studied in less detail. Some PMF studies include EC and OC (Ramadan et al., 2000; Song et al., 2001; Liu et al., 2003). Zhao and Hopke (2006) distinguished four different OC and three different EC fractions depending on the thermal stability, as well as organic pyrolized carbon. Selected Aerodyne AMS data were incorporated in factor analytical modelling by $\mathrm{Li}$ et al. (2004) (inorganics and OC); isolated organic fragments were used by Quinn et al. (2006) ( $\mathrm{m} / \mathrm{z}$ 's 44 and 57) and Buset et al. (2006) ( $m / z$ 's 43, 44 and 57) in multivariate analyses.

In the present study, 270 highly time-resolved organic fragments (mass-to-charge ratios, $\mathrm{m} / \mathrm{z}$ ) retrieved from an Aerodyne AMS (Jayne et al., 2000; Jimenez et al., 2003) were analyzed with PMF. When the factors and scores that result from PMF calculations are interpreted as aerosol sources and source strengths, respectively, it is necessary to verify these interpretations. Thus, the resulting scores were correlated with species that are indicative of primary (e.g. $\mathrm{CO}, \mathrm{NO}_{\mathrm{x}}$ ) and secondary (e.g. gaseous oxidants, particulate nitrate and sulphate) components in the troposphere. It was further examined whether the calculated scores are capable of reproducing emission events of dominant aerosol sources that were observed during the sampling period. Moreover, the spectral similarity of the PMF calculated factors and AMS reference spectra was evaluated. Finally, the variances in generally accepted marker $m / z$ 's (e.g. $\mathrm{m} / \mathrm{z} 44$ for oxidized aerosol spectra) that can be explained by the resulting factor, $E V(F)$ (Paatero, 2000), were inspected.

\section{Measurements}

The site of Zurich-Kaserne represents an urban background location in the centre of a metropolitan area of about one million inhabitants. The sampling site is at a public backyard, adjacent to a district with a high density of restaurants (West) and about $500 \mathrm{~m}$ from the main train station (Northeast). An Aerodyne AMS with a quadrupole mass spectrometer was deployed during three weeks in summer 2005 (from 14 July to 4 August). A detailed description of the AMS measurement principles (Jayne et al., 2000) its modes of operation (Jimenez et al., 2003) and data analysis (Alfarra et al., 2004; Allan et al., 2003, 2004) are provided elsewhere. Meteorological parameters and trace gases were measured with conventional instruments by the Swiss National Air Pollution Monitoring Network, NABEL (Empa, 2005): ten minute mean values of nitrogen oxides $\left(\mathrm{NO}_{\mathrm{x}}\right)$ were measured using chemiluminescence instruments with molybdenum converters (APNA 360, Horiba, Kyoto, Japan), a non-dispersive infrared (NDIR) technique was used to determine carbon monoxide (CO) (APMA 360, Horiba, Kyoto, Japan), and ozone was determined by UV absorption (TEI 49C, Thermo Electron Corp., Waltham, MA). Hourly organic carbon (OC) and elemental carbon (EC) data was retrieved from a semicontinuous EC/OC analyser (Sunset Laboratory Inc., Tigard, $\mathrm{OR})$.

The sampling period is characterized by two phases of elevated photochemical activity - indicated by high temperatures - each followed by rainfall (Fig. 1). Fireworks 


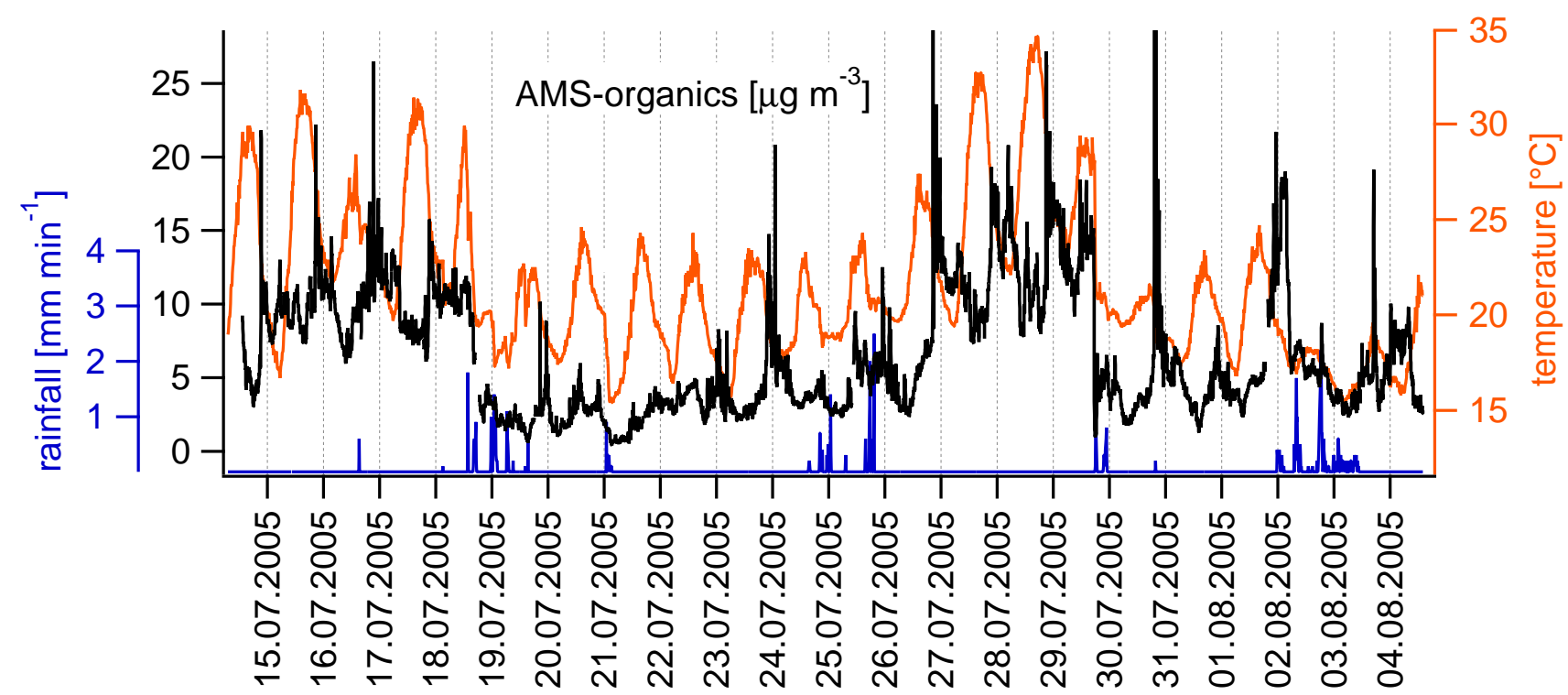

Fig. 1. Measured organics (values above $30 \mu \mathrm{g} \mathrm{m}^{-3}$ are not shown), temperature and rainfall during the sampling campaign at ZurichKaserne. Aerosol concentrations are given for a $\mathrm{CE}$ of unity.

on the Swiss national holiday (night of 1 August) are included. Nearby log-fires, charbroiling events and delivery vans caused other isolated peaks of organic aerosol (Fig. 1).

A total number of about 15000 mass spectra (MS) were acquired (averaging time $=2 \mathrm{~min}$ ). These MS are defined by vectors of 300 elements $\left(\mathrm{m} / \mathrm{z}^{\prime} \mathrm{s}\right) .270$ elements contain reliable information about the organic aerosol phase $(\mathrm{m} / \mathrm{z}, 12$ 13, 15-20, 24-27, 29-31, 37-38, 41-45, 48-148, 150-181, 185 , and $187-300$ ). The other $\mathrm{m} / \mathrm{z}$ 's were excluded due to dominant contributions of the air signals (e.g. $m / z 28,32$ and 40 for $\mathrm{N}_{2}, \mathrm{O}_{2}$ and $\mathrm{Ar}$, respectively), inorganic species (e.g. $\mathrm{m} / \mathrm{z}, 39$ and 46 for $\mathrm{K}$ and nitrate, respectively), high background levels (e.g. $\mathrm{m} / \mathrm{z}$ 186) or lack of plausible organic fragments (e.g. $m / z<12$ ). For more details on the interpretation of organic fragments see Allan et al. (2004) and Zhang et al. (2005a).

A collection efficiency (CE) value is required for the estimation of aerosol mass concentration measured by the AMS (Alfarra et al., 2004). Due to the lack of collocated $\mathrm{PM}_{1}$ measurements, a value of unity was used for the results reported in this study. This provides a lower limit estimation of the absolute mass concentrations, but does not influence the findings and the conclusions of this study since major results are reported in percentages of total organic mass.

\section{Data analysis}

Statistical analyses were carried out with the statistical software R version 2.1.1 (http://www.r-project.org, GNU GENERAL PUBLIC LICENSE Version 2, June 1991) and IGOR PRO 5.02 (Wavemetrics Inc., Lake Oswego, OR). Vectors are represented by bold italic letters, matrices by uppercase bold letters. Single vector and matrix elements as well as equations are written in lowercase italic letters.

\subsection{Positive matrix factorization (PMF)}

PMF is a well-established program to solve functional mixing models and is based on the work of Paatero and Tapper (1994) and Paatero (1997). The associated software "PMF2" (version 4.2) was used in this study. PMF can be used to solve receptor-only models and is most useful when source profiles are unknown. The fundamental principle of receptor modelling is that mass conservation can be assumed and a mass balance analysis can be used to identify and apportion sources of airborne particulate matter in the atmosphere (Hopke, 2003). The most important advantages of the PMF program compared to common receptor modeling techniques are that it uses a least-squares algorithm taking data uncertainty into account and that its solutions are restricted to the non-negative subspace. Both features lay the foundation of making the link between the mathematical solution and the processes of the real world possible. In practice, sources are better separated and positive scores and loadings are physically meaningful (Huang et al., 1999).

$\mathrm{PMF}$ is a factor analytical program for bilinear un-mixing of data measured at a receptor site. In PMF, the mass balance equation

$\mathbf{X}=\mathbf{G F}$

is solved, with the measured data matrix, $\mathbf{X}$, that combines $m$ measurements (in time) of $n$ variables ( $m \times n$ matrix). The $p$ rows of the $\mathbf{F}$ matrix ( $p \times n$ matrix) are called factors (or 
loadings), the columns of the $m \times p$ matrix $\mathbf{G}$ are called scores. The factors can often be interpreted as emission source profiles, the corresponding source activity is then represented by the scores. However, the number of sources, $p$, that have an impact on the data is typically unknown. Moreover, for a certain number of factors $p$, there is an infinite number of mathematically correct solutions to (1) given by rotated matrices $\mathbf{G}^{\prime}=\mathbf{G} \mathbf{T}$ and $\mathbf{F}^{\prime}=\mathbf{T}^{-1} \mathbf{F}$ (where the rotation matrix, $\mathbf{T}$, multiplied by its inverse, $\mathbf{T}^{-1}$, equals the identity matrix). Most of these solutions are physically meaningless due to negativity. Therefore, PMF imposes non-negativity constraints to the unmixed matrix elements. In this study, data matrix $\mathbf{X}$ consists of $j=1 \ldots n$ measured organic $m / z$ 's at $i=1 \ldots m$ samples in time, ORG. The matrix product of scores, $\mathbf{G}$, and factors, $\mathbf{F}$, defines the modelled organics, ÔRG.

$\mathbf{X}=\mathbf{O R G}_{i j}=\sum_{k=1}^{p} \mathbf{G}_{i k} \mathbf{F}_{k j}+\mathbf{E}_{i j}=\mathbf{O} \hat{\mathbf{R}} \mathbf{G}_{i j}+\mathbf{E}_{i j}$

where $p$ is the number of factors (or remaining dimensions of the original 270-dimensional space) and matrix $\mathbf{E}$ the model error. In this equation, $\mathbf{F}_{k j}$ is the modelled profile and and $\mathbf{G}_{i k}$ the modelled activity of factor $k$. Choosing the right number of factors or dimensions is a critical step in PMF. Often interpretability of $\mathbf{G}$ and $\mathbf{F}$ (along with diagnostic PMF values) is set as criterion for the optimum $p$. This step requires a priori knowledge and is highly subjective. Section 4.1 will be dedicated to this issue.

Factor matrices $\mathbf{G}$ and $\mathbf{F}$ form an approximate bilinear decomposition of ORG. This factor analysis problem is solved by minimizing the error, $\mathbf{E}$, weighted by measurement uncertainty matrix, $\mathbf{S}$, (weighted least square solved by a GaussNewton algorithm):

$Q=\arg \min _{G} \min _{F} \sum_{i=1}^{m} \sum_{j=1}^{n}\left(\frac{\mathbf{O R G}_{i j}-\mathbf{G}_{i k} \mathbf{F}_{k j}}{\mathbf{S}_{i j}}\right)^{2}$,

meaning that the value of the argument of the uncertainty (S) weighted difference between the measured (ORG) and modelled (GF) data matrix is at its minimum with respect to both fitting factors, the columns of $\mathbf{G}$ as well as the rows of F.

Thus, accurate uncertainty estimates of measured data are needed. Error estimates for a given AMS signal in $[\mathrm{Hz}]$

$s_{j}=\alpha \sqrt{\frac{\left(I_{j o}+I_{j b}\right)}{t_{s}}}$

were calculated from the ion signals of $m / z j, I_{j o}$ and $I_{j b}$ (taking into account that the ion signal at blocked aerosol beam, $I_{j b}$, is subtracted from the open beam signal, $I_{j o}$, in order to calculate the ultimate AMS signal), sampling time, $t_{s}$, and a statistical distribution factor, $\alpha$, and then transferred into organic-equivalent concentrations (org-eq. $\mu \mathrm{g} \mathrm{m}^{-3}$ ) using the IGOR PRO 5.02 code based on the work of Allan et al. (2003; http://cloudbase.phy.umist.ac.uk/people/allan/ ja_igor.htm). PMF was run in the non-robust mode. Other parameters were set to default values and no data pre-treatment was performed.

\subsection{Interpretation of factors and scores}

For interpretation of the factors (rows of $\mathbf{F}$ ) calculated by PMF, they were normalized and compared to measured reference spectra (Sects. 3.2.1 and 4.2). The corresponding scores (columns of $\mathbf{G}$ ) were correlated with indicative marker species of sources and atmospheric processes (Sect. 4.4). Note that both matrices, $\mathbf{G}$ and $\mathbf{F}$, have to be estimated from the data without assuming any a priori knowledge (with the exception of general non-negativity constraints for the matrix elements). When factors are interpreted as source profiles or aerosol components, they will be labelled with the name of the source or aerosol component. The corresponding scores are then called source activities.

\subsubsection{Spectral similarity and reference spectra}

The intensities of all obtained loadings (interpreted as mass spectra, $\boldsymbol{m s}_{j}$ ) with $j=1 \ldots 270 \mathrm{~m} / z$ 's were first normalized

$\boldsymbol{m} \boldsymbol{s}_{j}^{\text {norm. }}=\boldsymbol{m} \boldsymbol{s}_{j} / \sum_{j} \boldsymbol{m} \boldsymbol{s}_{j}$.

The normalized spectra ( $\left.\boldsymbol{m} \boldsymbol{s}_{j}^{\text {norm. }}\right)$ were then correlated with normalized reference spectra from literature $\left(\boldsymbol{m} \boldsymbol{s}_{j}^{\text {ref.,norm. }}\right)$ and the coefficient of determination $\left(R^{2}\right)$ was calculated as a measure of spectral similarity. This gives an objective and sensitive (e.g. the $R^{2}$ of the mass spectra of diesel and fulvic acid used in this study is 0.03 ) measure of spectral similarity. Further, it has been applied in similar previous publications (e.g. Zhang et al., 2005a) and is widely applicable and commonly used. The suitability of $R^{2}$ as a measure of spectral similarity has been validated by comparing it to other measures of distance, such as an uncertainty-weighted Euclidian distance, that allowed for the same interpretation. This approach however might have some shortcomings when it is applied to AMS spectra as such, e.g. the possible leverage effect of a few, high intensity masses (e.g. $\mathrm{m} / \mathrm{z}$. 18, 29, 43, $44)$ in regression analysis. These masses are typically small $(m / z \leq 44)$. Therefore, spectral similarity was also calculated for $m / z>44, R_{m / z>44}^{2}$, providing additional insight into the similarity of the low intensity masses only (values in parentheses; Table 1). The use of both values yields a more robust assessment of similarity.

Reference spectra used for transformed OA include fulvic acid (a model compound that describes the chemical functionality of aged, oxygenated aerosol; Alfarra, 2004), secondary organic aerosols from VOC precursors such as $\alpha$-pinene, isoprene, 1,3,5-trimethylbenzene, m-xylene, and cyclopentene (Bahreini et al., 2005; Alfarra et al., 2006a), as well as aged rural and urban aerosol from field studies 
Table 1. Spectral similarity for all $\mathrm{m} / \mathrm{z}^{\text {'s }}$ (and $\mathrm{m} / \mathrm{z}>44$ only) with a selection of illustrative reference spectra $\left(R^{2} \geq \mathbf{0 . 9 0}, R^{2} \geq \mathbf{0 . 8 0}\right.$ and $R^{2} \geq 0.70$ ) from Alfarra (2004) $)^{1}$, Zhang et al. $(2005 \mathrm{a})^{2}$, Alfarra et al. (2006a) ${ }^{3}$, Bahreini et al. $(2004)^{4}$, Alfarra et al. $(2006 \mathrm{~b})^{5}$, Schneider et al. $(2006)^{6}$, Canagaratna et al. (2004) ${ }^{7}$, this study (Sect. 3.2.1 $)^{8}$. Although the factors of all models are labelled according to spectral similarities here, only the factors of the final six-factorial solution model should interpreted as sources and aerosol components.

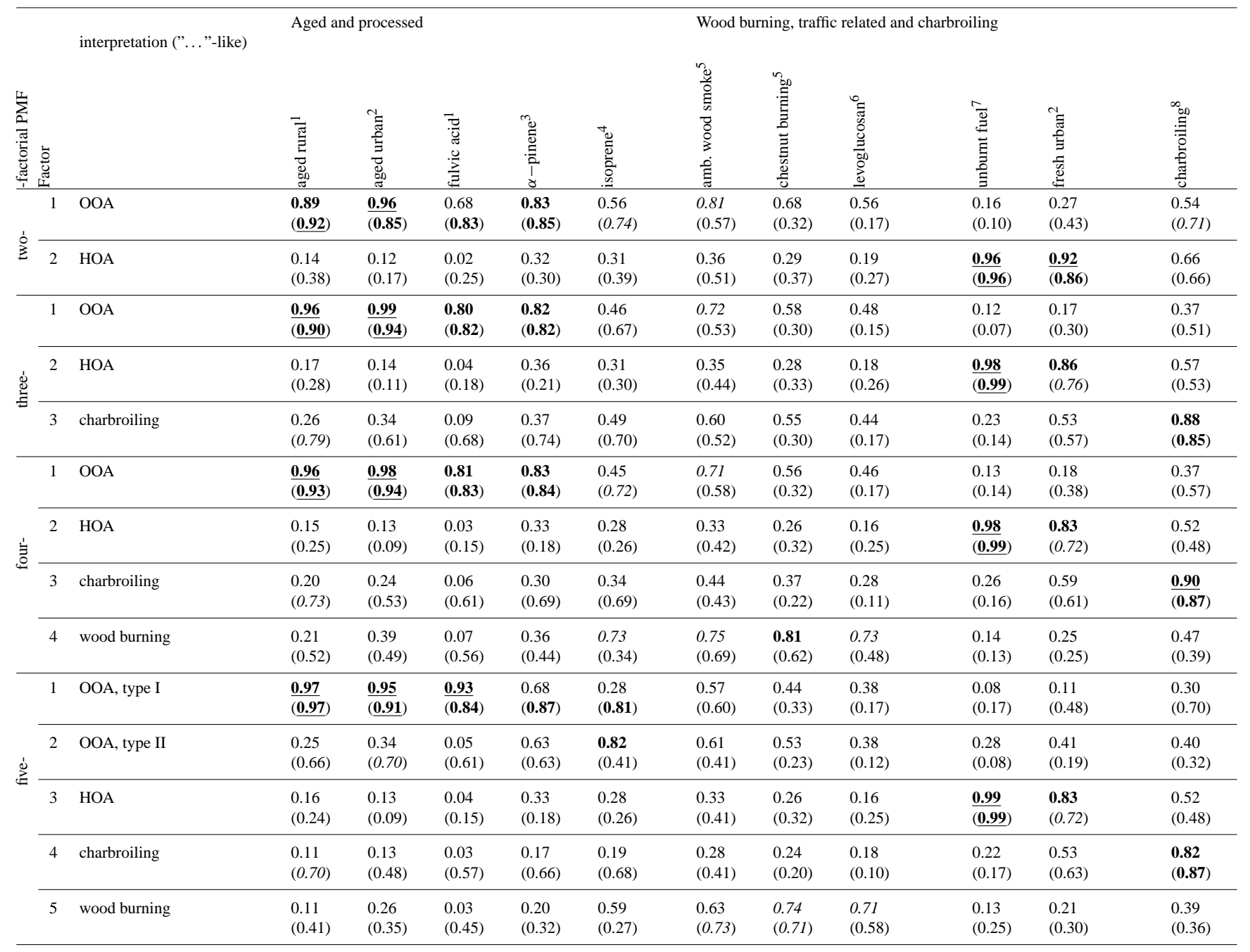

in Pittsburgh (Zhang et al., 2005a), Vancouver (Alfarra et al., 2004) and Manchester (Alfarra, 2004). At these places, spectra of freshly emitted combustion particles were determined, too. During several evenings of the sampling campaign at Zurich-Kaserne, charbroiling had been observed. To calculate the charbroiling reference spectra, the corresponding peaks were isolated and the background was subtracted. Background was defined as the samples before and after the barbecue events that were within the same meteorological regime and without interference from other known special emission situations such as pure hydrocarbon plumes, fireworks on 1 August and others. Reference spectra for wood burning in the field were obtained by AMS measurements in Roveredo, Switzerland, where wood burning was found to be the dominant source of organic aerosol in winter-time (Alfarra et al., 2006 $\mathrm{b}^{1}$ ). Additional reference spectra for wood combustion were provided by the MS of the cellulose pyrolysis tracer levoglucosan (Schneider et al., 2006) and combustion of many different wood types (e.g. chestnut, oak, beech, spruce, Alfarra et al., 2006 $\mathrm{b}^{1}$; Schneider et al., 2006). Canagaratna et al. (2004) performed chasing experiments of diesel vehicles in New York; in addition, spectra of pure diesel fuel and lubricant oil were obtained in the lab. A comparison of our obtained spectra with an illustrative selection of the reference spectra is shown in Table 1. It contains the comparisons

\footnotetext{
${ }^{1}$ Alfarra, M. R., Prévôt, A. S. H., Szidat, S., et al.: Identification of the mass spectral signature of organic aerosols from wood burning emissions, Environ. Sci. Technol., submitted, 2006b.
} 
Table 1. Continued.

\begin{tabular}{|c|c|c|c|c|c|c|c|c|c|c|c|c|c|}
\hline \multirow{2}{*}{\multicolumn{2}{|c|}{ 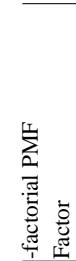 }} & \multirow{2}{*}{ interpretation ("..."-like) } & \multicolumn{5}{|c|}{ Aged and processed } & \multicolumn{6}{|c|}{ Wood burning, traffic related and charbroiling } \\
\hline & & & 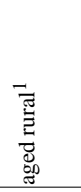 & 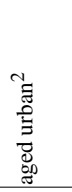 & 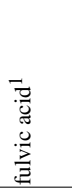 & $\begin{array}{l}3 \\
0 \\
0 \\
0 \\
1 \\
0 \\
0\end{array}$ & 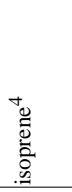 & 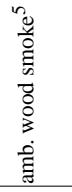 & 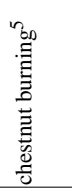 & 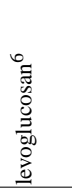 & 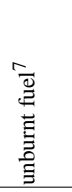 & 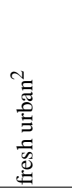 & 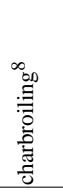 \\
\hline \multirow{6}{*}{$\frac{\dot{x}}{w}$} & 1 & OOA, type I & $\underline{\underline{0.96}}$ & $\frac{0.93}{(\underline{0.93})}$ & $\frac{0.96}{(0.83)}$ & $\begin{array}{l}0.63 \\
(\mathbf{0 . 8 4})\end{array}$ & $\begin{array}{l}0.23 \\
(0.79)\end{array}$ & $\begin{array}{l}0.52 \\
(0.62)\end{array}$ & $\begin{array}{l}0.40 \\
(0.35)\end{array}$ & $\begin{array}{l}0.35 \\
(0.19)\end{array}$ & $\begin{array}{l}0.06 \\
(0.18)\end{array}$ & $\begin{array}{l}0.08 \\
(0.45)\end{array}$ & $\begin{array}{l}0.25 \\
(0.65\end{array}$ \\
\hline & 2 & OOA, type II & $\begin{array}{l}0.27 \\
(\mathbf{0 . 8 6})\end{array}$ & $\begin{array}{l}0.34 \\
(0.79)\end{array}$ & $\begin{array}{l}0.05 \\
(0.75)\end{array}$ & $\begin{array}{l}0.65 \\
(\mathbf{0 . 8 3})\end{array}$ & $\begin{array}{l}\mathbf{0 . 8 0} \\
(0.65)\end{array}$ & $\begin{array}{l}0.62 \\
(0.51)\end{array}$ & $\begin{array}{l}0.53 \\
(0.27)\end{array}$ & $\begin{array}{l}0.37 \\
(0.13)\end{array}$ & $\begin{array}{l}0.33 \\
(0.16)\end{array}$ & $\begin{array}{l}0.50 \\
(0.42)\end{array}$ & $\begin{array}{l}0.49 \\
(0.61\end{array}$ \\
\hline & 3 & HOA & $\begin{array}{l}0.15 \\
(0.23)\end{array}$ & $\begin{array}{l}0.12 \\
(0.08)\end{array}$ & $\begin{array}{l}0.03 \\
(0.14)\end{array}$ & $\begin{array}{l}0.32 \\
(0.16)\end{array}$ & $\begin{array}{l}0.27 \\
(0.25)\end{array}$ & $\begin{array}{l}0.31 \\
(0.40)\end{array}$ & $\begin{array}{l}0.25 \\
(0.32)\end{array}$ & $\begin{array}{l}0.15 \\
(0.25)\end{array}$ & $\frac{0.99}{(\underline{0.99})}$ & $\begin{array}{l}\mathbf{0 . 8 1} \\
(0.70)\end{array}$ & $\begin{array}{l}0.50 \\
(0.46\end{array}$ \\
\hline & 4 & charbroiling & $\begin{array}{l}0.18 \\
(0.70)\end{array}$ & $\begin{array}{l}0.19 \\
(0.49)\end{array}$ & $\begin{array}{l}0.06 \\
(0.57)\end{array}$ & $\begin{array}{l}0.23 \\
(0.67)\end{array}$ & $\begin{array}{l}0.22 \\
(0.68)\end{array}$ & $\begin{array}{l}0.33 \\
(0.40)\end{array}$ & $\begin{array}{l}0.28 \\
(0.19)\end{array}$ & $\begin{array}{l}0.20 \\
(0.09)\end{array}$ & $\begin{array}{l}0.23 \\
(0.16)\end{array}$ & $\begin{array}{l}0.54 \\
(0.61)\end{array}$ & $\begin{array}{l}0.85 \\
(0.86\end{array}$ \\
\hline & 5 & wood burning & $\begin{array}{l}0.26 \\
(0.40)\end{array}$ & $\begin{array}{l}0.46 \\
(0.35)\end{array}$ & $\begin{array}{l}0.17 \\
(0.45)\end{array}$ & $\begin{array}{l}0.28 \\
(0.29)\end{array}$ & $\begin{array}{l}0.56 \\
(0.28)\end{array}$ & $\begin{array}{l}0.73 \\
(0.74)\end{array}$ & $\begin{array}{l}\mathbf{0 . 8 2} \\
(0.74)\end{array}$ & $\begin{array}{l}\mathbf{0 . 8 2} \\
(0.63)\end{array}$ & $\begin{array}{l}0.09 \\
(0.23)\end{array}$ & $\begin{array}{l}0.15 \\
(0.27)\end{array}$ & $\begin{array}{l}0.38 \\
(0.34\end{array}$ \\
\hline & 6 & minor/cooking & $\begin{array}{l}0.24 \\
(0.62)\end{array}$ & $\begin{array}{l}0.33 \\
(0.48)\end{array}$ & $\begin{array}{l}0.05 \\
(0.53)\end{array}$ & $\begin{array}{l}0.50 \\
(0.57)\end{array}$ & $\begin{array}{l}0.70 \\
(0.45)\end{array}$ & $\begin{array}{l}0.67 \\
(0.54)\end{array}$ & $\begin{array}{l}0.63 \\
(0.36)\end{array}$ & $\begin{array}{l}0.46 \\
(0.22)\end{array}$ & $\begin{array}{l}0.35 \\
(0.28)\end{array}$ & $\begin{array}{l}0.53 \\
(0.47)\end{array}$ & $\begin{array}{l}0.64 \\
(0.58\end{array}$ \\
\hline \multirow{7}{*}{ 离 } & 1 & OOA, type I & $\underline{0.94}(\underline{0.95})$ & $\frac{0.90}{(\underline{0.92})}$ & $\frac{0.97}{(0.82)}$ & $\begin{array}{l}0.60 \\
(\mathbf{0 . 8 3})\end{array}$ & $\begin{array}{l}0.20 \\
(0.79)\end{array}$ & $\begin{array}{l}0.48 \\
(0.61)\end{array}$ & $\begin{array}{l}0.37 \\
(0.34)\end{array}$ & $\begin{array}{l}0.32 \\
(0.18)\end{array}$ & $\begin{array}{l}0.05 \\
(0.19)\end{array}$ & $\begin{array}{l}0.07 \\
(0.46)\end{array}$ & $\begin{array}{l}0.23 \\
(0.65\end{array}$ \\
\hline & 2 & OOA, type II & $\begin{array}{l}0.26 \\
(\mathbf{0 . 8 6})\end{array}$ & $\begin{array}{l}0.33 \\
(0.79)\end{array}$ & $\begin{array}{l}0.05 \\
(0.74)\end{array}$ & $\begin{array}{l}0.65 \\
(\mathbf{0 . 8 3})\end{array}$ & $\begin{array}{l}0.79 \\
(0.64)\end{array}$ & $\begin{array}{l}0.60 \\
(0.50)\end{array}$ & $\begin{array}{l}0.51 \\
(0.26)\end{array}$ & $\begin{array}{l}0.35 \\
(0.12)\end{array}$ & $\begin{array}{l}0.33 \\
(0.15)\end{array}$ & $\begin{array}{l}0.49 \\
(0.40)\end{array}$ & $\begin{array}{l}0.47 \\
(0.59\end{array}$ \\
\hline & 3 & charbroiling & $\begin{array}{l}0.18 \\
(0.70)\end{array}$ & $\begin{array}{l}0.20 \\
(0.50)\end{array}$ & $\begin{array}{l}0.06 \\
(0.57)\end{array}$ & $\begin{array}{l}0.24 \\
(0.67)\end{array}$ & $\begin{array}{l}0.23 \\
(0.68)\end{array}$ & $\begin{array}{l}0.34 \\
(0.40)\end{array}$ & $\begin{array}{l}0.28 \\
(0.19)\end{array}$ & $\begin{array}{l}0.21 \\
(0.09)\end{array}$ & $\begin{array}{l}0.24 \\
(0.15)\end{array}$ & $\begin{array}{l}0.55 \\
(0.61)\end{array}$ & $\begin{array}{l}0.86 \\
(0.86\end{array}$ \\
\hline & 4 & HOA & $\begin{array}{l}0.14 \\
(0.24)\end{array}$ & $\begin{array}{l}0.11 \\
(0.09)\end{array}$ & $\begin{array}{l}0.03 \\
(0.15)\end{array}$ & $\begin{array}{l}0.31 \\
(0.17)\end{array}$ & $\begin{array}{l}0.27 \\
(0.26)\end{array}$ & $\begin{array}{l}0.31 \\
(0.41)\end{array}$ & $\begin{array}{l}0.24 \\
(0.32)\end{array}$ & $\begin{array}{l}0.15 \\
(0.25)\end{array}$ & $\frac{0.99}{(\underline{0.99})}$ & $\begin{array}{l}\mathbf{0 . 8 2} \\
(0.72)\end{array}$ & $\begin{array}{l}0.51 \\
(0.47\end{array}$ \\
\hline & 5 & wood burning & $\begin{array}{l}0.45 \\
(0.47)\end{array}$ & $\begin{array}{l}0.65 \\
(0.42)\end{array}$ & $\begin{array}{l}0.36 \\
(0.46)\end{array}$ & $\begin{array}{l}0.37 \\
(0.32)\end{array}$ & $\begin{array}{l}0.54 \\
(0.35)\end{array}$ & $\begin{array}{l}0.77 \\
(\mathbf{0 . 8 4})\end{array}$ & $\begin{array}{l}0.82 \\
(0.83)\end{array}$ & $\begin{array}{l}\mathbf{0 . 8 3} \\
(0.71)\end{array}$ & $\begin{array}{l}0.08 \\
(0.31)\end{array}$ & $\begin{array}{l}0.12 \\
(0.36)\end{array}$ & $\begin{array}{l}0.37 \\
(0.44\end{array}$ \\
\hline & 6 & minor/unknown & $\begin{array}{l}0.34 \\
(0.46)\end{array}$ & $\begin{array}{l}0.44 \\
(0.37)\end{array}$ & $\begin{array}{l}0.15 \\
(0.49)\end{array}$ & $\begin{array}{l}0.46 \\
(0.43)\end{array}$ & $\begin{array}{l}0.56 \\
(0.35)\end{array}$ & $\begin{array}{l}0.70 \\
(0.49)\end{array}$ & $\begin{array}{l}0.69 \\
(0.38)\end{array}$ & $\begin{array}{l}0.55 \\
(0.26)\end{array}$ & $\begin{array}{l}0.25 \\
(0.18)\end{array}$ & $\begin{array}{l}0.40 \\
(0.32)\end{array}$ & $\begin{array}{l}0.63 \\
(0.42\end{array}$ \\
\hline & 7 & minor/cooking & $\begin{array}{l}0.29 \\
(0.61)\end{array}$ & $\begin{array}{l}0.38 \\
(0.47)\end{array}$ & $\begin{array}{l}0.08 \\
(0.50)\end{array}$ & $\begin{array}{l}0.52 \\
(0.55)\end{array}$ & $\begin{array}{l}0.70 \\
(0.46)\end{array}$ & $\begin{array}{l}0.71 \\
(0.54)\end{array}$ & $\begin{array}{l}0.67 \\
(0.35)\end{array}$ & $\begin{array}{l}0.51 \\
(0.22)\end{array}$ & $\begin{array}{l}0.35 \\
(0.29)\end{array}$ & $\begin{array}{l}0.53 \\
(0.49)\end{array}$ & $\begin{array}{l}0.67 \\
(0.59\end{array}$ \\
\hline
\end{tabular}

of all factors deduced from 2- to 7-factorial PMF ( $\mathrm{n}=27$ ) with the selected reference spectra $(\mathrm{n}=11)$. This comparison is based on spectral similarities $R^{2}$ and $R_{m / z>44}^{2}$ (in brackets) as defined before. The most interesting results of this 594 element table will be discussed in detail later in Sect. 4.2.

\section{Results and discussion}

\subsection{Determination of the number of factors}

In PMF, choosing the number of factors often needs a compromise. Using too few factors will coerce sources of different types into one factor, while using too many will split real sources into unreal factors. PMF is a descriptive model and there is no objective criterion to choose the ideal solution.

"Interpretability" (or "meaningfulness") is frequently used to determine the number of factors (e.g. Li et al., 2004; Buset et al., 2006). Mathematical PMF diagnostics (model error, $Q$, rotational ambiguity, rotmat, etc.) characterize technical aspects of the solution. However, they do not guarantee the best solution in terms of explaining real-world phenomena. Rigorous testing of the plausibility of PMF solutions (that are basically blind to atmospheric processes) should be based on accompanying measurements of trace gases, aerosols and meteorology (Sects. 4.2, 4.4 and 4.5).

\subsubsection{Mathematical diagnostics}

For the 6-factorial solution, only a small fraction $(<1 \%)$ of the scaled residuals, $\mathbf{E}$ (scaled) or $(\mathbf{X}-\mathbf{G F}) / \mathbf{S}$, exceeds the default outlier limits of -4 and 4 (the most explanatory power is given for the 6-factorial solution as discussed in Sect. 4.2). The total sum of squared scaled residuals (Eq. 3), $Q$, relative to its expected value, Q.exp, that can be approximated by the number of data matrix elements, does not exceed a value of about two for models with more than two factors. The ratio $Q /$ Q.exp is about one for six and more factors (Fig. 2a), meaning that error estimates based on Eq. (4) are accurate 


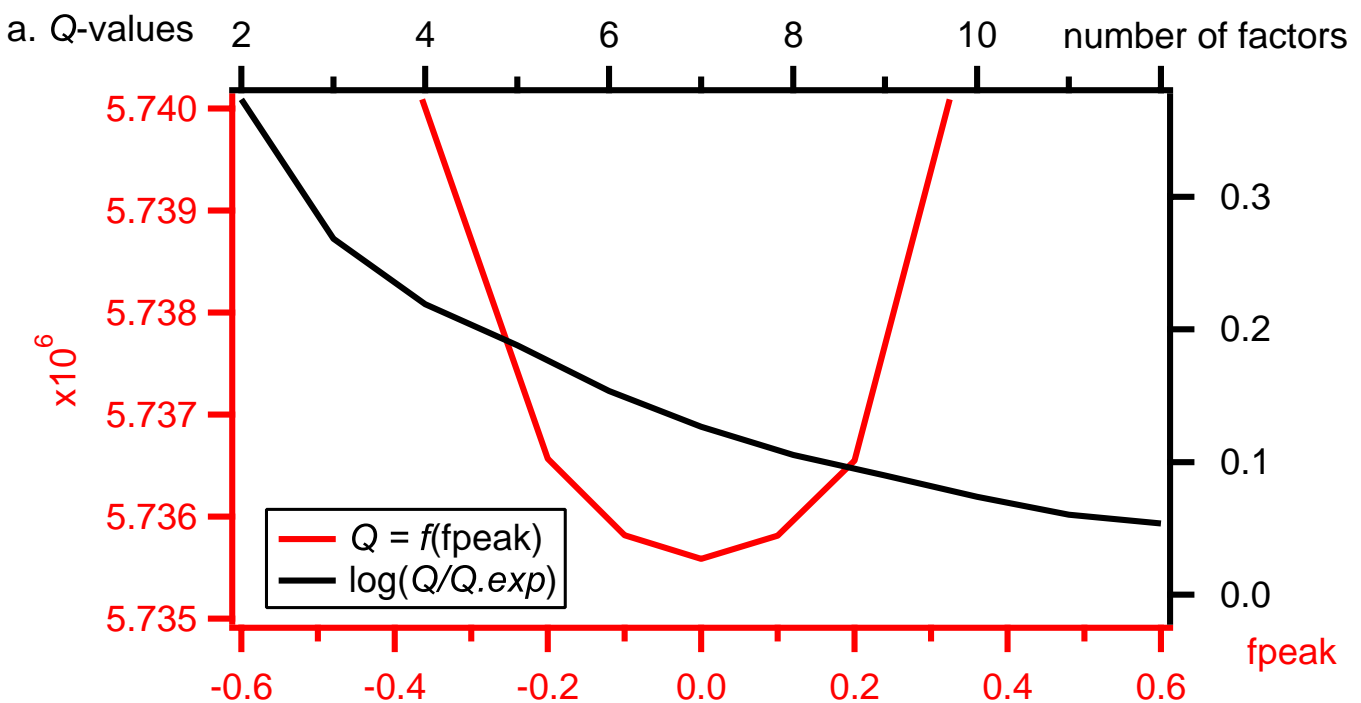

b. $Q$ contributions and signal-to-noise ratios (SNR)

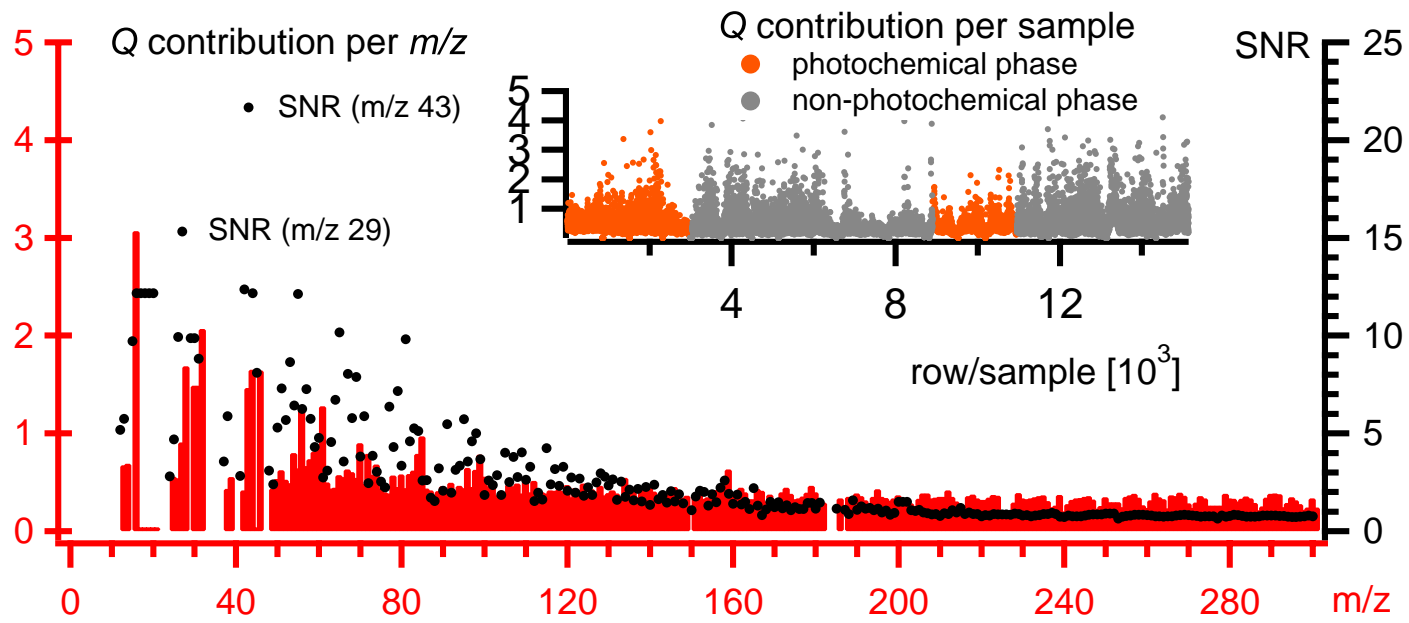

c. model fit $\left(\mathrm{R}^{2}\right)$, rotational ambiguity (max(rotmat))

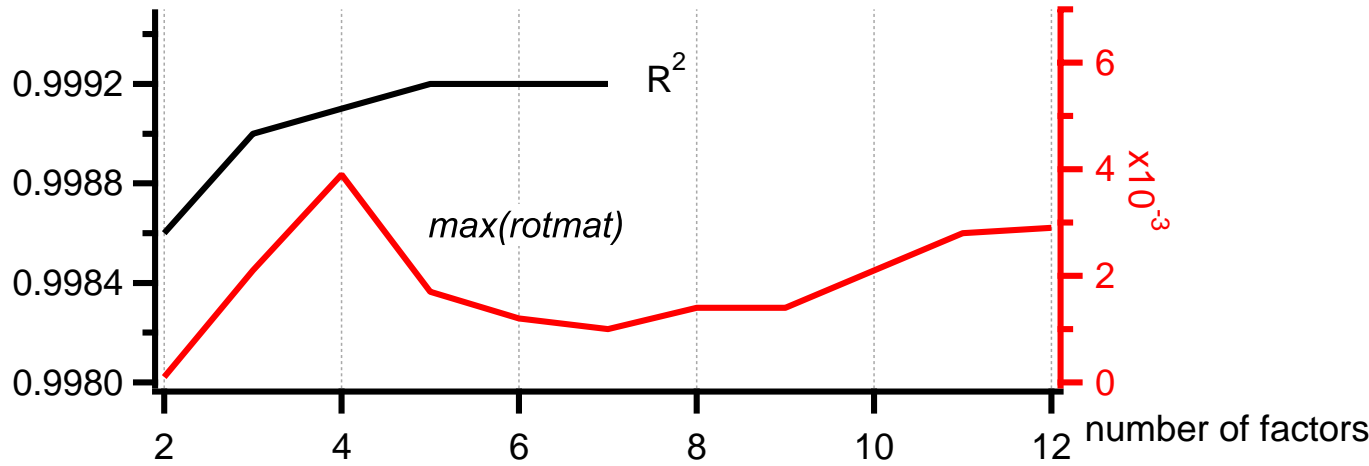

Fig. 2. (a) $Q$-values for different factorial solutions relative to the expected $Q$-values, $Q$.exp. The absolute $Q$-value as a function of the "fpeak"-parameter (red) is shown for the six-factorial solution. (b) Average signal-to-noise ratios (SNR) for each measured organic fragment $\mathrm{m} / \mathrm{z}$ (black dots), median $Q$ contributions of each column (or $\mathrm{m} / \mathrm{z}$; red) and each row (or sample in time). The $Q$ contribution per row is shown for the photochemical phases (orange dots) as well as for the non-photochemical phases (gray dots). (c) Goodness of fit $\left(R^{2}\right)$ of regressed scores vs. measured total organics and rotational freedom as a function of the number of factors chosen in PMF. 

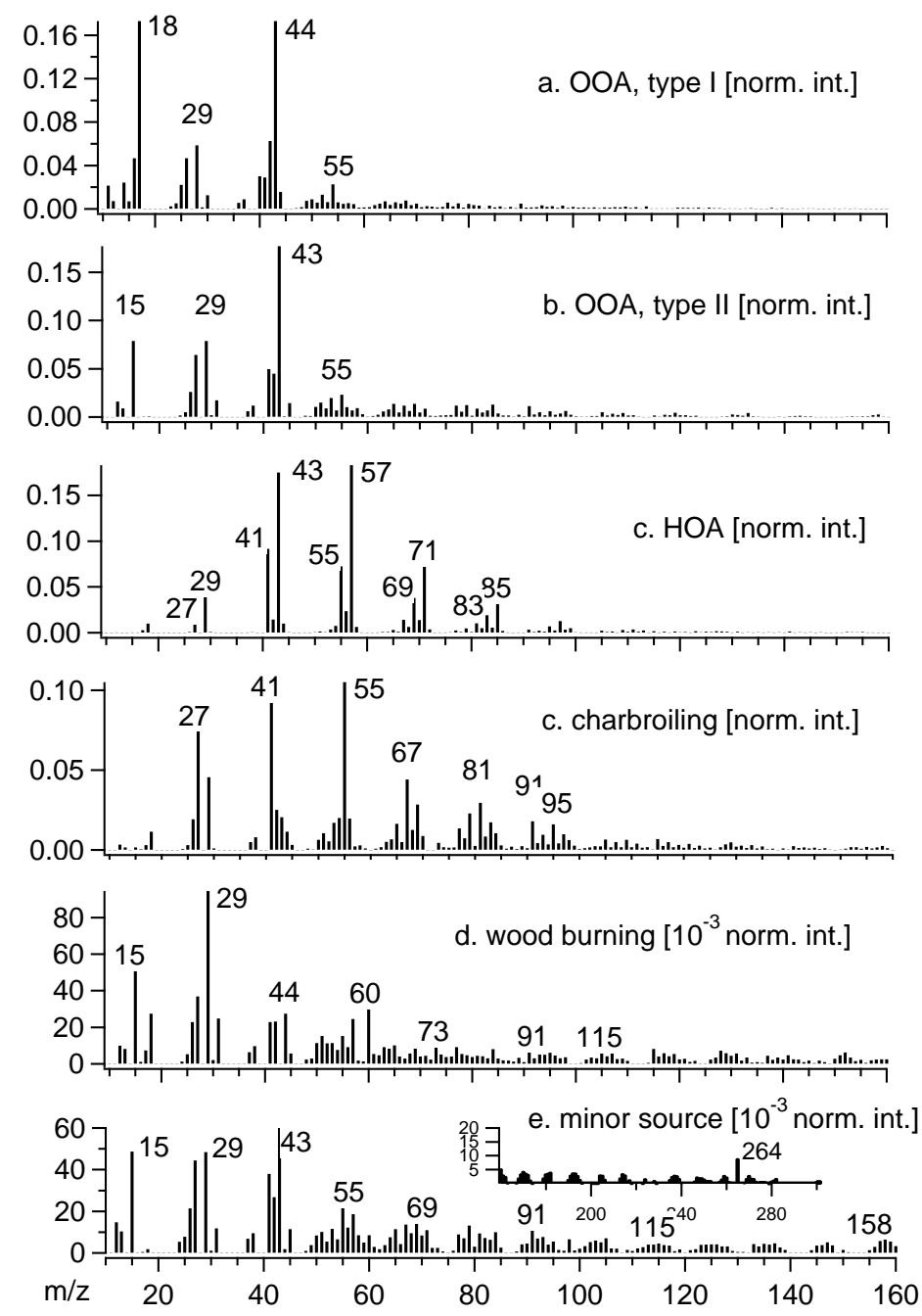

Fig. 3. Spectra of all PMF factors (interpreted as the denoted source profiles) calculated by 6-factorial PMF. Only for the minor source the full mass range up to $300 \mathrm{~m} / \mathrm{z}$ is shown because it is the only source or component with significant features in the high mass region on the linear scale.

or at least not too small for the present model. The absolute $Q$ value for the 6-factorial solution is shown in Fig. 2a as a function of the "fpeak"-value.

An "fpeak"-range of $[0.0, \pm 0.1, \pm 0.2, \pm 0.4, \pm 0.6, \pm 0.8]$ has been investigated: forcing the solution to extreme $\mathbf{F}$ and G elements and allowing only few values of intermediate size worsens interpretability as well as the model fit, i.e. this type of rotation increases the residuals associated with the model to some extent (as shown in Fig. 2a). Those findings suggest that a central rotation ("fpeak" $=0.0$ ) should be used for analyzing the present data set.

The median $Q$ contribution of each column or $\mathrm{m} / \mathrm{z}$ organic fragment, $\overline{\boldsymbol{e}}_{\mathrm{j}}(\text { scaled })^{2}$, and row or sample, $\overline{\boldsymbol{e}}_{\mathrm{i}}(\text { scaled })^{2}$, is shown in Fig. 2b. A decrease of signal-to-noise ratios (SNR, also shown in Fig. 2b) can be observed with increasing mass-to-charge ratios $\left(\mathrm{m} / \mathrm{z}^{\prime} \mathrm{s}\right)$ of the organic fragments. The $Q$ contribution per column decreases as well as a func- tion of $m / z$, indicating that high masses do not disproportionately contribute to the model error. In contrast, analyzing only organic fragments with $\mathrm{SNR} \geqslant 3$, say, yields a suboptimum aerosol source resolution for this data set. Also note that phases of increased photochemical activity do not show increased modelling errors, indicating that reactivity can adequately be described by the model.

The largest element in rotmat, $\max$ (rotmat), has been suggested as an estimate for the worst case rotational ambiguity (Lee et al., 1999). The rotmat values should however only be interpreted qualitatively (Paatero, 2000) and are not suited as a unique criterion for the determination of the number of factors as it appears that no general validity may be inherent to such an approach (Paatero, 2007). A solution with rotational ambiguity means that the algorithm finds only vector sets that are linear superpositions of the principal components. This represents a mathematical drawback 
as the solution is not unique, i.e. the resolved factors can be rotated without changing the residuals associated with the model (rotational ambiguity hampers the qualitative interpretation of the results). There are three local minima in max (rotmat) versus number of factors shown in Fig. 2c: one at two factors $(\max ($ rotmat $)=0.0001)$ and one at seven factors $(\max ($ rotmat $)=0.0010)$. Values similar to the second minimum can be found from five to nine factors, supporting the actual choice of $p=6$ factors based on interpretability. The 2factorial solution with lowest rotational ambiguity exhibits suboptimum aerosol source resolution as discussed below (e.g. see Sect. 4.3). The third local minimum is at 15 factors $(\max ($ rotmat $)=0.0026)$, but uninterpretable factors (e.g. overwhelming dominance of $\mathrm{m} / \mathrm{z} 15$ or $\mathrm{m} / \mathrm{z}$ 41) can be observed as soon as the number of sources is increased from seven to eight (in Sect. 4.2 we describe what happens, when the number of factors is gradually increased from two to seven sources).

In addition, the fit of the regressed scores to measured organics for all PMF solutions was investigated,

$\boldsymbol{o r g}_{i}=a+\sum_{k=1}^{p} b_{k} \boldsymbol{g}_{i k}$

A better fit is obtained by increasing the number of factors from two to five. In this case, a plateau is reached at five factors $\left(R^{2}=0.9992\right)$. Even with only two factors, already $99.86 \%$ of the variance of the measured organics (i.e. the time series of total organics) can be explained by the model (note that errors in the reconstructed data matrix are discussed above as well as in Sect. 4.3). The intercept $a$ is virtually zero and the overall slope is 1.00 for any PMF model introduced. The products $b_{k} \boldsymbol{g}_{i k}$ in Eq. (6) represent normalized scores and are estimates for the contributions of each source to total organics. They are shown for $p=6$ as absolute values (Fig. 6) and as relative values (Fig. 4). This normalization is most promising when the aim is to estimate accurate source contributions. However, it is important to note that the spectral similarity (Sects. 3.2.1 and 4.2), the correlation of scores with indicative species (Sect. 4.4) as well as the approximation of the data matrix (reconstructed organics as discussed in Sect. 3.1 and calculated in Sect. 4.3) are invariant to factor normalization.

\subsection{Interpretation of factors and mass allocation}

The source profiles and their activities will be discussed in order of decreasing explained variation, $E V(F)$, as described in Paatero (2000). It is a measure of how important each factor is in explaining the variance in the $m / z$ 's. The order of discussion is reflected in Table 1.

Each factor (or calculated MS) of the 6-factorial PMF is presented in Fig. 3. This figure shows the normalized intensity (according to Eq. 5) versus mass-to-charge ratio of all six factors retrieved from PMF. As specific calculated spectra (e.g. HOA-like factors) from different factorial approaches show less variability than a certain group of the reference spectra (e.g. all spectra referring to wood burning), the selection of 6-factorial solutions is representative for the factors that are not shown here. It is the 6-factorial solution that includes the highest number of interpretable factors and we will proceed with when the discussion turns to source activities. In this section, the discussion includes all solutions of 2- to 7-factorial PMF analyses.

The PMF factors are named based on spectral similarities to reference spectra. Except for the best model (6-factorial solution), the suffix "-like" is added to the names of the factors, because factors should only be interpreted as sources and aerosol components for the final and validated model.

\subsubsection{Two-factorial solution}

Assuming two factors in PMF modelling, the first factor computed by PMF is most similar to OOA from Pittsburgh $\left(R^{2}=0.96\right)$, but also highly similar to all other OOA reference spectra obtained from field studies $\left(R^{2}>0.88\right)$. The second factor is closest to the diesel fuel MS $\left(R^{2}=0.96\right)$, but also similar to the MS from chasing experiments and lubricant oil $\left(R^{2}>0.93\right)$. The average mass associated with the OOA-like factor is $87 \%$, while $13 \%$ are allocated to the HOA-like factor (an overview of the average mass associated with each factor is summarized in Fig. 4). The OOA-like factor as well as the HOA-like factor calculated by PMF are virtually identical $\left(R^{2}=0.99, R_{m / z>44}^{2}=0.99\right.$ and $R^{2}=0.98, R_{m / z>44}^{2}=0.99$, respectively) to the corresponding factors calculated by using two first-guess principal components $(\mathrm{m} / \mathrm{z} 44$ and $\mathrm{m} / \mathrm{z} 57$; Zhang et al., 2005a).

\subsubsection{Three-factorial solution}

In the 3-factorial case, the first two factors generally exhibit more or less the same similarities to reference spectra as in the 2-factorial case. In fact, they are even slightly more similar to the spectra discussed above. The first factor is strongly correlated with secondary particles from Pittsburgh $\left(R^{2}=0.99\right)$ and the second factor has the highest correlation with the fuel reference MS $\left(R^{2}=0.98\right)$. The MS of the third factor is closely related to charbroiling $\left(R^{2}=0.88\right)$. A mean mass percentage of $63 \%$ is attributed to the OOA-like factor, $10 \%$ to the HOA-like factor, and $27 \%$ to charbroiling-like aerosol. These changes compared to the 2 -factorial model suggest that some primary particles (charbroiling and similar sources) are included in the OOA-like factor, when assuming only two factors (see also Sect. 4.3).

\subsubsection{Four-factorial solution}

When a fourth factor is introduced, the first three factors do not change much in terms of similarity with reference spectra. The new fourth factor shows highest similarity to wood smoke from the Roveredo field measurements $\left(R^{2}=0.81\right)$. Using four factors, about $12 \%$ of the OA mass originates 


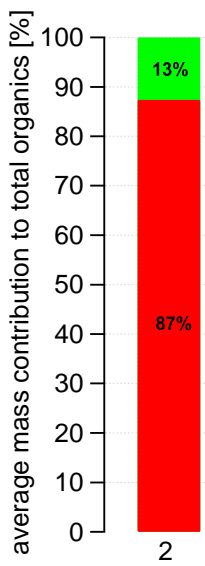

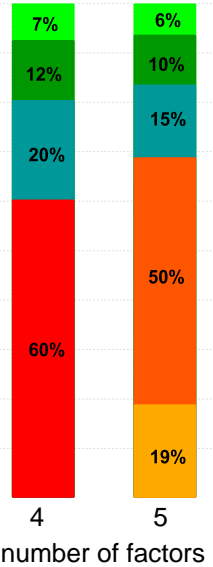
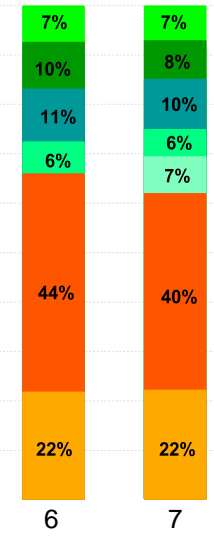

aerosol sources/components:

- $\mathrm{HOA}(-\mathrm{like})$

- wood burning(-like)

- charbroiling(-like)

- minor source (cooking)

minor source

- OOA(-like)

- OOA, type I

- OOA, type II

Fig. 4. Average mass allocation to each PMF-solution assuming two to seven factors.

from wood burning-like aerosol. When the wood burninglike factor is introduced, modelled mass from charbroilinglike aerosol is reduced most (difference between the mass attributed within the 3-factorial approach and the one within the 4 factorial approach: $\Delta_{\text {mass }}=-7 \%$ ).

\subsubsection{Five-factorial solution}

A dramatic change can be observed when five factors are used in PMF modelling: not as much in the change of max (rotmat) or the model fit (Sect. 4.1), but in terms of similarity to secondary aerosol. The original first, OOA-like factor is split into highly aged background aerosol (high similarity to aged rural aerosol: $R^{2}=0.97$ and to fulvic acid: $\left.R^{2}=0.93\right)$ and one that mostly resembles aerosol from isoprene oxidation in the presence of $\mathrm{NO}_{\mathrm{x}}\left(R^{2}=0.82\right)$. We will refer to these OOA factors as "OOA, type I" and "OOA, type II", respectively. The third spectrum is again associated with charbroiling $\left(R^{2}=0.82\right)$, the fourth with wood burning (similarity to Roveredo spectra: $R^{2}=0.70$; levoglucosan: $\left.R^{2}=0.71\right)$. Increasing the number of factors from four to five does not affect the modelled mass of wood burning-like aerosol $\left(\Delta_{\text {mass }}=-2 \%\right)$ or fuel-like aerosol $\left(\Delta_{\text {mass }}=-1 \%\right)$, while charbroiling-like aerosol again $\left(\Delta_{\text {mass }}=-6 \%\right)$ is losing most of its contribution. This indicates that using only three or four factors results in overestimating OA from charbroiling.

\subsubsection{Six-factorial solution}

With six factors, the first factor is even more similar to fulvic acid $\left(R^{2}=0.96\right)$, while the third factor is still very similar to fuel aerosol $\left(R^{2}=0.99\right)$. The second factor can be interpreted similarly as in the 5-factorial case. However, considering only $m / z>44$, correlations are highest with $\alpha$-pinene SOA rather than isoprene SOA. It should be noted that in reality SOA from several precursors will contribute to this fac- tor, where the differences between the reference spectra do not seem to be significant enough to discriminate between those. The fourth factor can be interpreted as a charbroiling source again $\left(R^{2}=0.85\right)$, the fifth is even more levoglucosanlike $\left(R^{2}=0.82\right)$. The sixth factor does not fit in any class of reference spectra, but there is an indication for a fragmentation that resembles an oleic acid type signature that may arise from food cooking: the mass spectrum of this factor is characterised by $\mathrm{m} / \mathrm{z} 264$ with an intensity of about $15 \%$ relative to the largest peak $(\mathrm{m} / \mathrm{z}, 43)$ and it is in the same range as $m / z, 60$ in this factor. This might be an indication of oleic acid (NIST, 2006), the most abundant monoenoic fatty acid in plant and animal tissues. On the other hand, Katrib et al. (2004) showed that $m / z 264$ is much more depleted in pure oleic acid than shown in this factor. Therefore, this is an indication that oleic acid might be lumped together with other similar fatty acids, such as petroselenic acid (which is present e.g. in coriander and parsley), pointing to food cooking as a partial source in that factor (additional evidence that this factor might include food cooking aerosols will be given in Sect. 4.4.3). However, a conclusive comparison should be based on measured reference spectra for food cooking aerosol rather than on the mass spectrum of model substances (such as oleic acid). To our knowledge, no such spectra can be found in the published AMS literature. Going from five to six factors, the average mass does not change for fuel-like aerosols. In general, mass differences for all factors are small $\left(\left|\Delta_{\text {mass }}\right| \leq 5 \%\right)$.

\subsubsection{Seven-factorial solution}

The first five factors in the 7-factorial solution are more or less the same as with six factors. The seventh factor, tentatively assigned to food cooking, remains unchanged too, while the sixth factor does not correlate well with any of the available reference spectra: similarity is highest with the wood burning MS but correlations are lower than for the 
fifth factor. If the sixth factor is added to the fifth factor (interpreted as wood burning), the resulting factor exhibits increased correlation $\left(R^{2}=0.84, R_{m / z>44}^{2}=0.87\right)$ to ambient wood burning aerosols from Roveredo (but the same or lower correlation to other measured wood smoke spectra). This indicates that splitting real sources into unreal factors by assuming too many factors might already start at 7 -factorial solutions to some extent. In addition, no more significant changes in the mass contribution to total organics take place, when we assume seven instead of six factors: charbroilinglike $(10 \%)$ and traffic-related fuel aerosol $(6 \%)$ aerosol remain at constant levels, the minor source that might be influenced by food cooking $\left(\Delta_{\text {mass }}=-1 \%\right)$ and aerosol that resembles OOA from local precursors $\left(\Delta_{\text {mass }}=+1 \%\right)$ are almost unchanged.

\subsubsection{Evaluation of 2- to 7-factorial solutions}

In summary, choosing only two factors in factor analytical models for this site overestimates OOA if interpreted as SOA. At sites with two dominating sources this may be less critical; as an example, Zhang et al. (2006) ${ }^{2}$ show that this OOA overestimation does not apply for the Pittsburgh dataset.

When three and more factors are assumed, aerosol from primary sources is subtracted from the OOA-like factor and this first factor exhibits higher correlations with the mass spectrum of fulvic acid.

The similarity of this first factor to fulvic acid is mainly increased when the number of factors is changed from two to three as well as from four to five. About $85-90 \%$ percent of the overall $\mathrm{m} / \mathrm{z} 44$ variance can be explained by this first factor. Evidence for $m / z, 44$ and $m / z, 57$ as tracers for oxygenated and hydrocarbon aerosol was first given in Alfarra et al. (2004).

A HOA-like factor is salient from 2- to 7-factorial PMF. The fraction of OA explained by the HOA-like factor is decreasing from $13 \%$ in the 2-factorial approach to $6-7 \%$ in the 4- to 7-factorial approaches. The similarity to fuel is already strong when using only two factors. Strongest similarity is reached when five factors are used. Most of the variance in the diesel marker $\mathrm{m} / \mathrm{z}, 57$ can be explained by the HOAlike factor. In the 2 -factorial case, this amounts to $80 \%$ and monotonously decreases with each additional source down to about $50 \%$. The wood burning-like factor explains $12-13 \%$ of the $m / 257$ variance.

When only three factors are chosen, wood burning-like aerosol is mainly lumped together with charbroiling-like aerosol (Sect. 4.2.3). Adding a fourth factor takes account of the fact that there is wood burning in summer (log-fires,

\footnotetext{
${ }^{2}$ Zhang, Q., Jimenez, J.-L., Dzepina, K., et al.: Component analysis of organic aerosols in urban, rural, and remote site atmospheres based on aerosol mass spectrometry, 7th International Aerosol Conference, poster 5H8, St. Paul, Minnesota, USA, 2006.
}

barbecues, as well as domestic garden and forest wood burning). At least four factors are necessary to identify wood burning. The factor identified as wood burning explains 45$55 \%$ of all variance in $\mathrm{m} / \mathrm{z}, 60$. About $25 \%$ of $\mathrm{m} / \mathrm{z}, 60$ cannot be explained by the PMF models. About $25 \%$ of the $\mathrm{m} / \mathrm{z} 73$ variance is explained by the charbroiling factor and nearly $20 \%$ by the wood burning factor, while $23 \%$ remain unexplained. Mass-to-charge ratio 60 and 73, as well as 137 have been linked to wood burning by Schneider et al. (2006) as well as by Alfarra et al. (2006b) $)^{1}$. The wood burning-like factor can account for 30-45\% of the $\mathrm{m} / z 137$ variance, and about $30 \%$ can not be explained by the model.

When a fifth factor is assumed, OOA is divided into highly aged background aerosol, which is fulvic acid-like and a second type that can not be clearly assigned to any reference MS (considering both, $R^{2}$ and $R_{m / z>44}^{2}$, see Table 1). Choosing five, six or seven factors does not affect the solution significantly. Choosing more than seven factors generates source profiles that cannot be interpreted. Changes from six to seven factors are very small. Additionally, the average mass associated with each source does not change much when we increase the number of factors from five to six factors, and even less when choosing seven instead of six factors (Fig. 4). With five factors, the similarity plateau (defined by $R^{2}$ of 7-factorial solutions, which typically exhibit the highest values) is not attained in most cases (Table 1), whereas the similarity to isoprene is highest with five factors. Therefore (and because of the findings from the 7-factorial solution, Sect. 4.2.6), using 6 factors might be a good compromise for further analyses. The spectra of these six factors are shown in Fig. 3.

\subsection{Primary sources contributing to OOA (calculated by 2- factorial PMF)}

In Sect. 4.2.2, it was hypothesized that the first factor of 2-factorial PMF (interpreted as OOA) includes oxidized species from primary sources. Further evidence that 2factorial PMF overestimates secondary aerosol at this site, if the factor interpreted as OOA is equated with SOA is given here. We would expect that periods of anticyclonic, stable weather conditions, when oxidized aerosol species from primary sources (e.g. charbroiling, wood burning, tobacco smoke, food cooking) interfere with oxidized secondary aerosols, are most erroneously modelled by using two-factors only. In such situations, the 2-factorial model is expected to be less accurate than for instance the 3 -factorial approach.

With respect to the time series of total organics, all used PMF approaches (2- to 7-factorial) can technically model the data almost perfectly (Sect. 4.1.1). However, the regression as given in Eq. (6) does not cover all matrix errors. Therefore, the error patterns in those models should be investigated by considering the sum of the absolute model residuals (or absolute differences between the measured data matrix, 


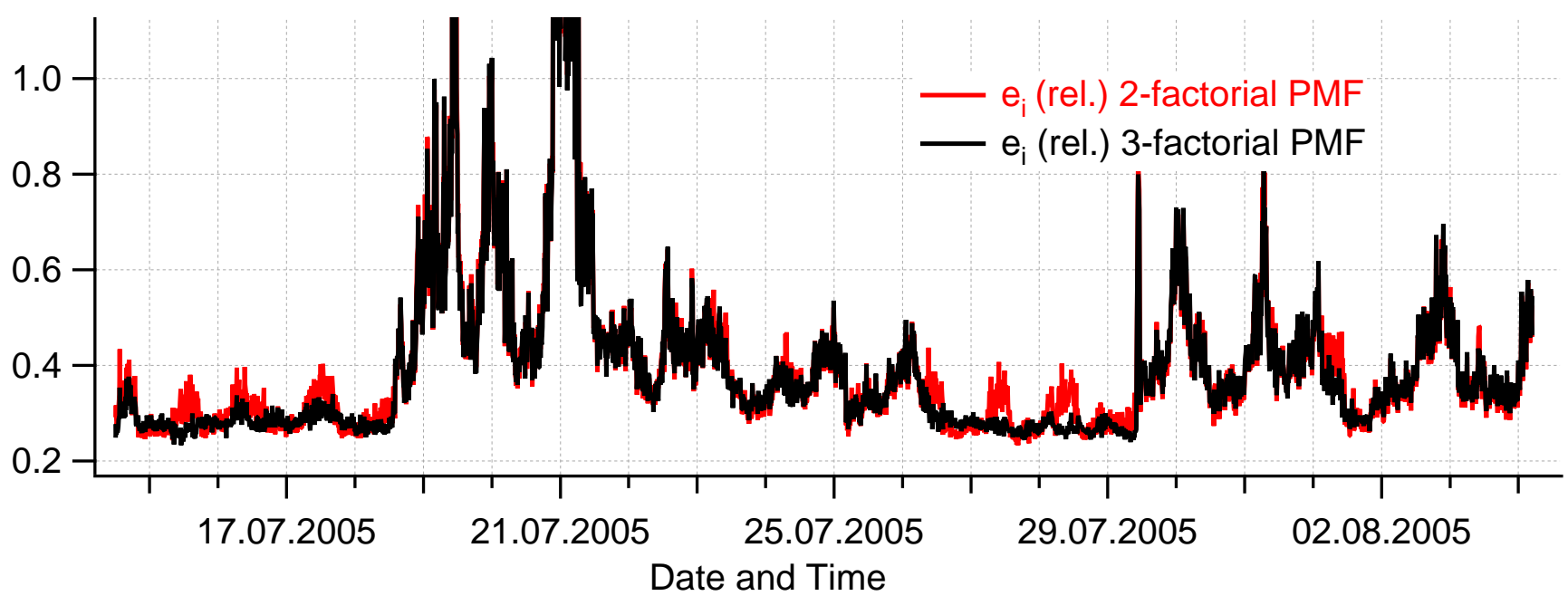

Fig. 5. Different error patterns in 2- and 3-factorial PMF. (The general error patterns of the 4- to 7-factorial solutions can be represented by the error pattern of the 3 -factorial solution.)

ORG, and its model approximate, $\mathbf{O} \hat{\mathbf{R}} \mathbf{G})$ divided by the sum of the measured organics.

$\boldsymbol{e}_{i}($ rel. $)=\frac{\sum_{j}\left|\mathbf{O R G}_{i j}-\mathbf{O R}_{i j}\right|}{\sum_{j} \mathbf{O R G}_{i j}}$

Periods of elevated photochemistry (as well as 1 August) are indeed more erroneously modelled by 2 -factorial PMF (Fig. 5) compared to the 3 -factor solution. In contrast, the errors, $\boldsymbol{e}_{i}$ (rel.), are more or less identical during periods of low photochemistry (19-25 July and 30 July-4 August; with the exception of the morning of 1 August). Note that for the squared scaled residuals $\left(\overline{\boldsymbol{e}}_{\mathrm{i}}(\boldsymbol{s c a l e d})^{2}\right)$ of the 6-factorial solution, those periods exhibit a similar error pattern (Fig. 2b).

\subsection{Interpretation of scores (activity of sources)}

\subsubsection{Processed and volatile OOA}

Particulate AMS-sulphate is correlated with OOA, type I $\left(R^{2}=0.52, \mathrm{n}=14914\right)$. Both time series are shown in Fig. 6 and all discussed correlations are presented in Table 2. Atmospheric oxidants $\left(\mathrm{O}_{3}+\mathrm{NO}_{2}\right)$ are also correlated to OOA, type I $\left(R^{2}=0.51\right)$, giving further evidence that OOA, type I refers to highly aged and processed organic aerosol. This OOA type is relatively stable during the photochemical period and exhibits a slight maximum in the afternoon, when temperature is highest. This suggests that the aerosol modelled by OOA, type I is thermodynamically stable. This is, together with the spectral similarity to fulvic acid, strongly indicating that OOA, type I represents aged, processed and possibly oligomerized OOA with low volatility as found in SOA from smog chamber studies (Kalberer et al., 2004).
In contrast, OOA, type II shows diurnal patterns with maxima typically found at night. During the photochemical phase, the baseline of OOA, type II is clearly elevated (Fig. 6). Both findings indicate a general accumulation of oxidation products formed during the day that condense onto pre-existing particles at night. This latter process is reflected by OOA, type II. Particle-nitrate retrieved from AMS measurements shows a high correlation $\left(R^{2}=0.55\right)$ with OOA, type II when the last fifth of the sampling period is excluded (see below). The particulate nitrate concentration depends strongly on temperature, as the formation of condensed phase ammonium nitrate is in a temperature and humidity dependent equilibrium with ammonia and nitric acid in the gas phase. These findings suggest that OOA, type II is a volatile fraction of OOA with high anti-correlation to the temperature (e.g. if we consider the first four days of the campaign - those are all associated with elevated photochemistry a relationship of OOA, type $\mathrm{II}=-0.13 \cdot$ temperature +5.09 , $R^{2}=0.47$, can be described). In fact, this volatile fraction of OOA is even more strongly dependent on temperature when its measurement series is shifted back in time about half a day $\left(R^{2}=0.66\right)$. This might suggest that concentrations are highest in the night after a day with high photochemical activity when more condensable organics are available. As of 1 August (the Swiss National day), the concentrations of measured nitrate and modelled OOA, type II diverge. These last days of the campaign are characterized by lower temperatures $\left(\mathrm{T}<23^{\circ} \mathrm{C}\right)$. This suggests that during this period photochemical oxidation of SOA precursors is low while the formation of nitrate is still high, possibly due to night-time chemistry. Also influences from fireworks on measured nitrate concentrations cannot be excluded. 
Table 2. Correlation of scores (or calculated source contributions) by 6-factorial PMF with indicative species of the gas- and aerosol phase and temperature, Temp. (selection of illustrative examples).

\begin{tabular}{|c|c|c|c|c|}
\hline & \multicolumn{4}{|c|}{$i$-th factor (interpreted as component/source) } \\
\hline & 1st factor (OOA I) & 2nd factor (OOA II) & 3rd factor $(\mathrm{HOA})$ & 4th factor (wood) \\
\hline $\begin{array}{l}\text { measurement }\left(R^{2}\right) \\
\text { represented process }\end{array}$ & $\begin{array}{l}\text { particle- } \mathrm{SO}_{4}^{2-}(0.52) \\
\text { secondary }\end{array}$ & $\begin{array}{l}\text { particle- } \mathrm{NO}_{3}^{-}(0.55) \\
\text { secondary/nightime } \\
\text { chemistry }\end{array}$ & $\begin{array}{l}\mathrm{NO}_{\mathrm{X}}(0.81) \\
\text { combustion }\end{array}$ & $\begin{array}{l}\mathrm{CO}(0.70) \\
\text { incomplete combustion }\end{array}$ \\
\hline $\begin{array}{l}\text { measurement }\left(R^{2}\right) \\
\text { represented process }\end{array}$ & $\begin{array}{l}\mathrm{O}_{3}+\mathrm{NO}_{2}(0.51) \\
\text { atmos. oxidation }\end{array}$ & $\begin{array}{l}\text { Temp. }(0.47,0.66) \\
\text { condensation } \\
(\text { anticorr. } \Delta \mathrm{t}=0, \\
\Delta \mathrm{t}=10 \mathrm{~h})\end{array}$ & $\begin{array}{l}\mathrm{CO}(0.74) \\
\text { incomplete combustion }\end{array}$ & $\begin{array}{l}\mathrm{NO}_{\mathrm{X}}(0.48) \\
\text { combustion }\end{array}$ \\
\hline
\end{tabular}

\subsubsection{HOA, charbroiling and wood burning aerosol}

Wood burning is better correlated with CO $\left(R^{2}=0.70\right.$, $\mathrm{n}=2793,7$ outliers $)$ than with $\mathrm{NO}_{\mathrm{x}}\left(R^{2}=0.48, \mathrm{n}=2800\right) . \mathrm{CO}$ is a tracer for incomplete combustion (in complete combustion processes, only $\mathrm{CO}_{2}$ is formed). We can expect that aerosols from domestic log-fires are often generated at low temperatures, favouring incomplete combustion and $\mathrm{CO}$ emissions. HOA shows a slightly better correlation with $\mathrm{CO}\left(R^{2}=0.81\right.$, $\mathrm{n}=2776,24$ outliers $)$, than with $\mathrm{NO}_{\mathrm{x}}\left(R^{2}=0.74, \mathrm{n}=2776,24\right.$ outliers). Both $\mathrm{CO}$ and $\mathrm{NO}_{\mathrm{x}}$ are emitted by vehicles. $\mathrm{NO}_{\mathrm{x}}$ is also strongly associated with diesel vehicle exhaust. Therefore, there is less discrepancy in the $R^{2}$ when HOA is correlated with $\mathrm{CO}$ and $\mathrm{NO}_{\mathrm{x}}$ than it is the case for domestic wood burning, as these latter particles are often generated at temperature where $\mathrm{NO}_{\mathrm{x}}$ is a minor product.

If a multiple linear regression is calculated for the 6factorial PMF results (primary sources only),

Tracer $=f(\mathrm{HOA}$, charbroiling, wood burning, minor source $)$,

the correlation is in the same range for Tracer=CO, yielding $R^{2}=0.88$ (21 outliers) as well as for Tracer $=\mathrm{NO}_{\mathrm{x}}\left(R^{2}=0.76\right.$, 29 outliers). This multiple correlation with the gaseous marker $\mathrm{NO}_{\mathrm{x}}$ does not improve much compared to the ordinary correlation of $\mathrm{NO}_{\mathrm{x}}$ with HOA (calculated with PMF). Hence, the HOA factor is sufficient to explain variances in $\mathrm{NO}_{\mathrm{x}}$.

Boxplots of HOA during days dominated by commuters and heavy traffic with moderate influence of leisure traffic and activities (Monday to Friday) were calculated and compared to the remaining days, which can all be (partially) characterized by leisure road traffic and activities: Saturdays (after-noon and evening activities) and Sundays (trucks are banned from roads), as well as Monday, 1 August (Swiss national holiday) (Fig. 7). For working days only, HOA exhibits a similar daily cycle as $\mathrm{NO}_{\mathrm{x}}$ which can be characterized by two peaks: one in the morning at 08:00 to 09:00 a.m. and one in the evening at about 09:00 to 10:00 p.m. For the weekend and holidays, these diurnal patterns differ: not as much in the morning, when both daily cycles do not increase (as of 05:00 a.m.), but in the evening as of 06:00 p.m., when HOA is significantly concentrated at higher levels (compared to morning hours). Therefore, sources other than on-road traffic might contribute to HOA. Note, however, that nitrogen oxides $\left(\mathrm{NO}_{\mathrm{x}}=\mathrm{NO}+\mathrm{NO}_{2}\right)$ also include substantial interferences by $\mathrm{NO}_{\mathrm{x}}$ oxidation products (Steinbacher et al., 2006), and are also emitted by lightning, biomass burning and industrial sources. In 2000, traffic sources contributed about $58 \%$ of total $\mathrm{NO}_{\mathrm{x}}$ emissions in Switzerland (EKL, 2005). Therefore, $\mathrm{NO}_{\mathrm{x}}$ is not a perfect traffic marker, and HOA should not be equated with pure vehicle exhaust either.

It is interesting to note the high wood burning concentrations compared to relatively low HOA and charbroiling contributions during the night from 1 August (Swiss national holiday) to 2 August (Fig. 6). This together with the outstanding sulphate peak is a strong indication that the wood burning factor is also influenced by emissions from the fireworks on the national holiday (fireworks consist of wood or wooden products, e.g. cardboard coating, and sulphur which is used for several purposes). However, the peaks of submicron sulphate concentrations disappear rapidly while the baseline of the modelled wood burning aerosol concentration is still increasing until the morning increase of the boundary layer height. Simultaneous log-fires from upwind places most probably dominate the wood smoke aerosol (Fig. 8). In fact, there are lots of wood fires from big stacks at many places during this evening. These fires will be smouldering far into the night, as actually also seen in Fig. 8.

In August $2002,{ }^{14} \mathrm{C}$ analyses were performed by Szidat et al. (2006) at Zurich-Kaserne. Based on assumed OC/EC values of wood burning for biomass emission factors they calculated that $13 \%$ of total organic matter stems from biomass burning. This is in good agreement with $10 \%$ wood burning contribution calculated in this study. Based on emission inventories we can rule out contributions of biomass burning sources other than wood combustion. In addition, as there is virtually no EC emission from charbroiling (shown e.g. by Schauer et al., 1999) it is unlikely that barbecue activities are 

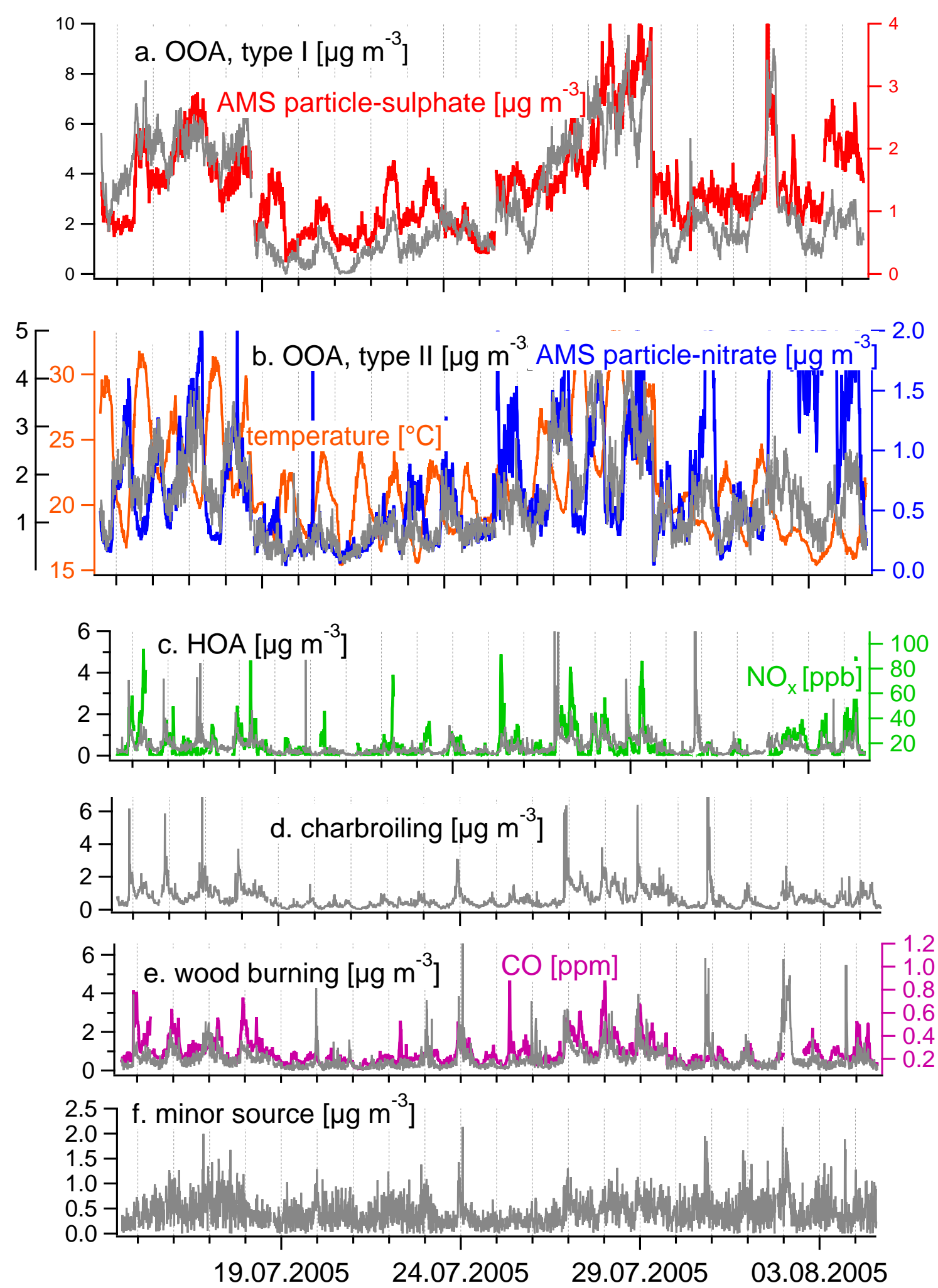

Fig. 6. Time series of the contributions of all identified sources and OA components as calculated by 6-factorial PMF: (a) OOA, type I and particulate sulphate (red), (b) OOA II and particle-nitrate (blue), (c) HOA and nitrogen oxides ( $\mathrm{NO}_{\mathrm{x}}$; green), (d) charbroiling, (e) wood burning and CO (violet), and (f) minor source (possibly influenced by food cooking). Aerosol concentrations are given for a CE of unity. 
a. HOA, working days

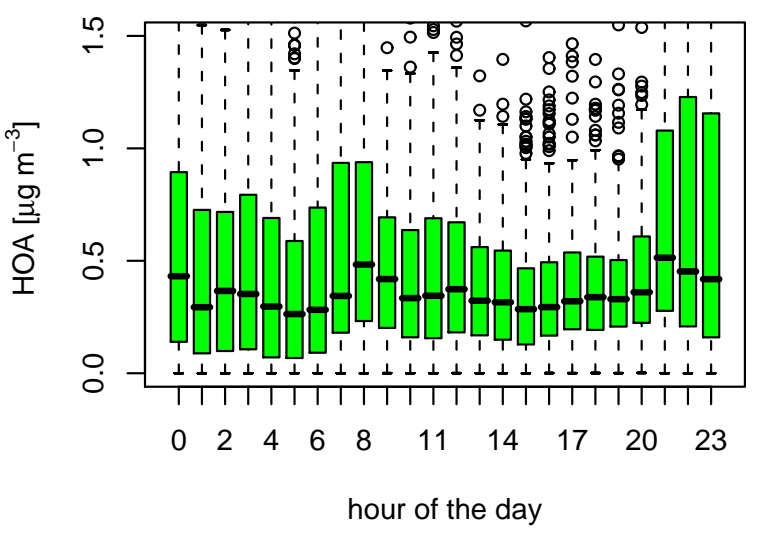

c. NOx, working days

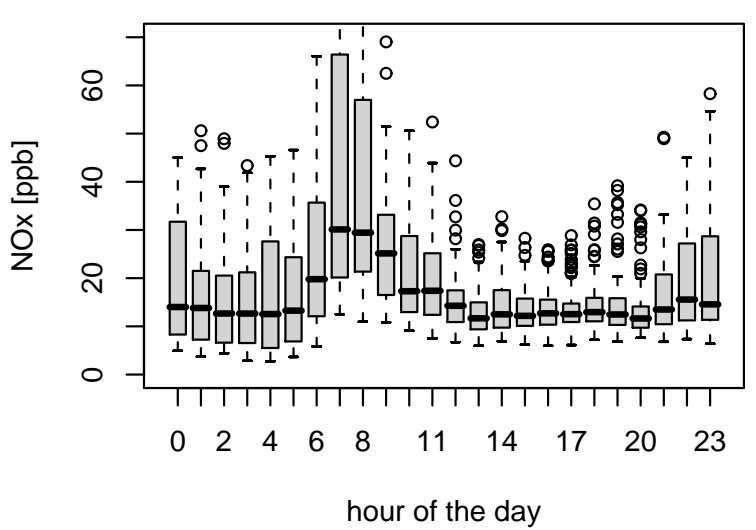

b. HOA, weekends and holidays

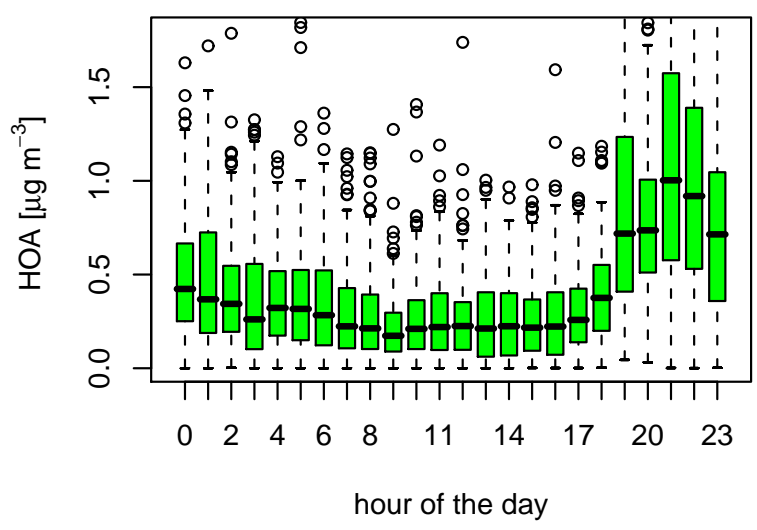

d. NOx, weekends and holidays

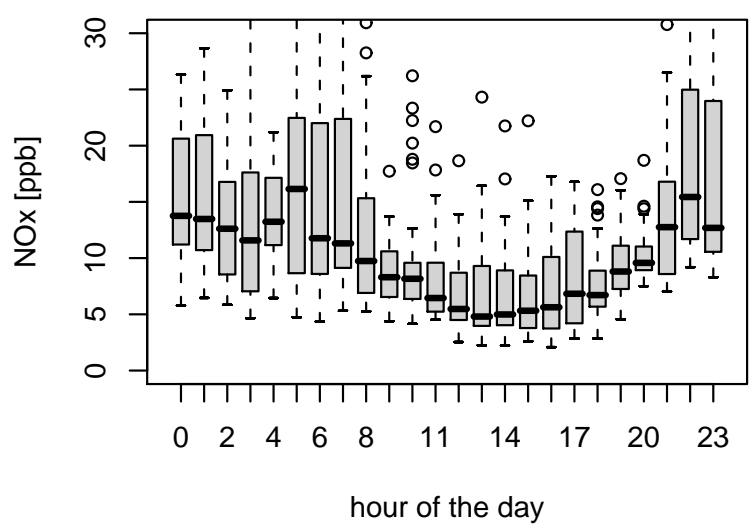

Fig. 7. Hourly boxplots for HOA (top) and $\mathrm{NO}_{\mathrm{x}}$ on working days (a and c, respectively) and on weekends as well as holidays (b and d, respectively). Horizontal black bars represent the group medians, vertical hinges represent data points from the lower to the upper quartile. Any data observation which lies more than 1.5 times the interquartile range, IQR, lower than the first quartile or 1.5 times IQR (T-symbol) higher than the third quartile is considered an outlier and represented by a circle. Aerosol concentration values are given for a CE of unity.

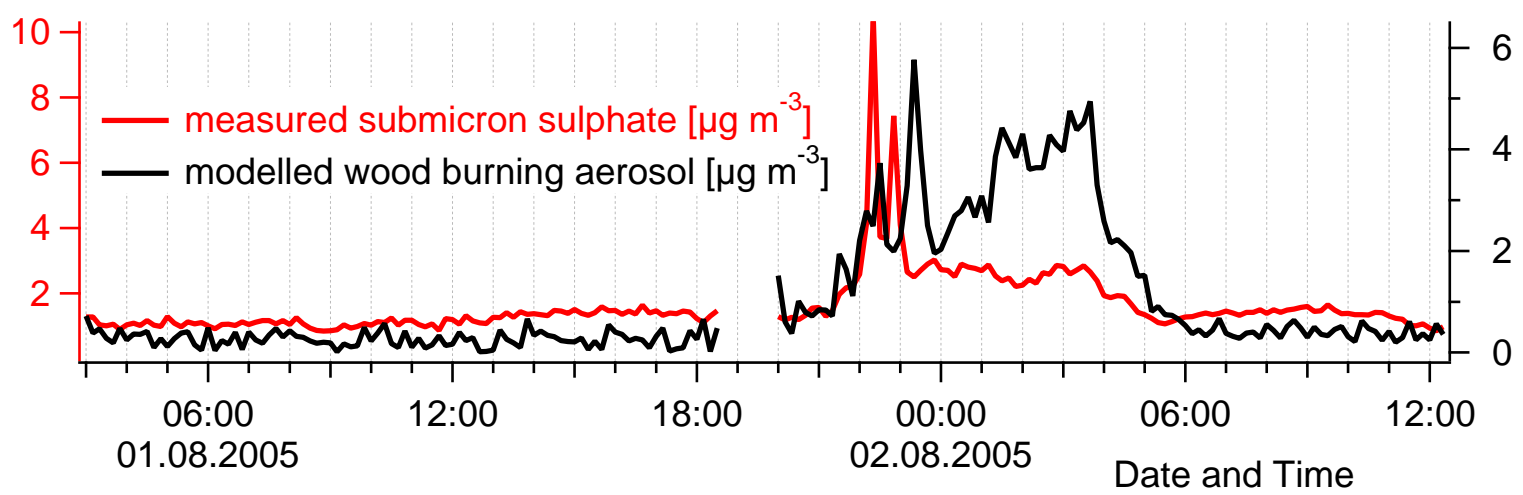

Fig. 8. Measured AMS-sulphate and modelled aerosol from wood burning on the Swiss national holiday (1 August). Concentration values are given for a CE of unity. 


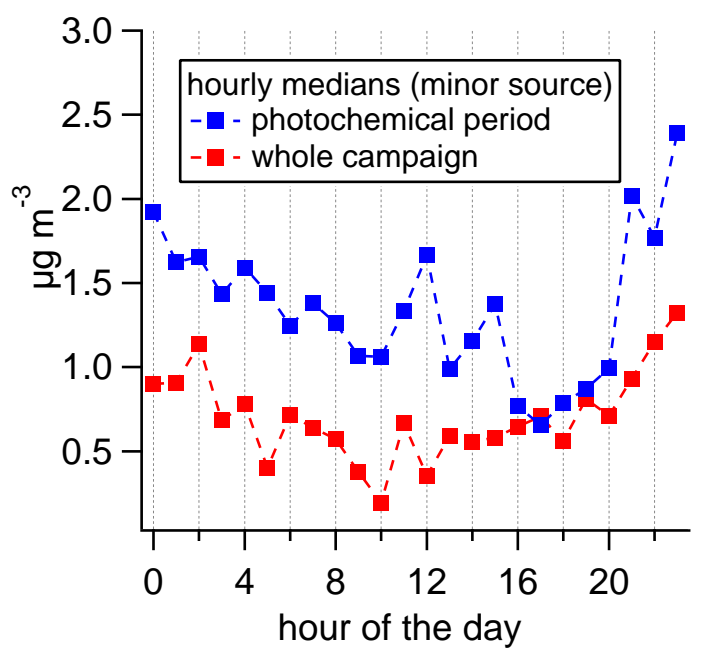

Fig. 9. Hourly median values of the sixth factor (minor source): calculated for the photochemical phase only and for the whole campaign. Concentration values are given for a $\mathrm{CE}$ of unity.

included in this $13 \%$ biomass burning (as biomass contributions were calculated from EC values).

High concentrations of charbroiling aerosols typically coincide with evenings of periods of warm temperatures (e.g. on 14-17 July; Figs. 1 and 6). Charbroiling emissions are probably highly variable with respect to their chemical composition (complete and incomplete combustion of accelerants, char, fat) and probably cannot be described by a single mass spectrum. Therefore, we might underestimate those emissions here. In summertime, both charbroiling and wood burning can be expected to be due to leisure activities. It is therefore not surprising that those time series are correlated (see Fig. 6).

\subsubsection{Minor source (influenced by food cooking)}

Some indications that the minor source may be influenced to some extent by food cooking has been provided in Sect. 4.2.5. Hourly medians were calculated for the modelled minor source time series and are presented in Fig. 9. An increase can observed in this factor at noon and from 08:00 to 09:00 p.m. during the photochemically active periods (14-18 and 26-29 July 2005; Fig. 1) which were accompanied with anticyclonic, stable weather conditions and more leisure activities. In contrast, there is no peak at noon and a less eminent increase in the concentration from 08:00 p.m. to 09:00 p.m. when the whole dataset is analyzed. Further evidence that the sixth factor can be interpreted as influenced by cooking is given by filtering the data with respect to wind direction.

\subsection{Wind direction}

An area of densely located restaurants ("LangstrassenQuartier") is in the direction of Northwest to Southwest, while air from North to East is coming from the main train station ("Zürich HB"). A minimal wind speed of $0.5 \mathrm{~m} / \mathrm{s}$ is imposed (wind direction and wind speed are measured $32.1 \mathrm{~m}$ above ground level). The busiest hours in that area are typically from 06:00 p.m. to 11:00 p.m. Aerosol concentrations from the sixth factor are significantly higher (mean: $0.52 \mu \mathrm{g} \mathrm{m}^{-3}$, standard deviation: $0.02 \mu \mathrm{g} \mathrm{m}^{-3}$ ) when air from the "Langstrassen-Quartier" arrived at the measuring site than when the wind came from the direction of the main train station (mean: $0.27 \mu \mathrm{g} \mathrm{m}^{-3}$, standard deviation: $0.03 \mu \mathrm{g} \mathrm{m}^{-3}$ ). Thus, a ratio of 1.9 can be calculated for aerosol from the "Langstrassen-Quartier" compared to "Zürich HB". Note that this phenomenon is untypical for other aerosol concentrations: no significant dependence on wind direction can be observed for the other primary factors (HOA, charbroiling and wood burning aerosol), and both OOA factors are lower in air masses from West (ratio of type I, aged fraction: 0.4 ; type II, volatile fraction: 0.7 ). Very similar results are obtained without applying the time filter. North-eastern winds ("Bise") during Swiss summers are typically anticyclonic and associated with clear sky and more solar radiation favouring atmospheric oxidation processes, while Western winds often contain wet air masses from the Atlantic Sea. This is an indication why OOA (especially type I) shows lower concentrations in Western air masses.

\subsection{Modelled emission ratios}

The emission ratios of modelled primary organic aerosol (POA) or HOA versus measured primary pollutants such as elemental carbon (EC), $\mathrm{NO}_{\mathrm{x}}$ and $\mathrm{CO}$ are calculated from the slope $s$ of the following linear regression modell:

$\mathrm{POA}=a+s \cdot($ measured primary pollutant $)+\varepsilon$

Based on the solution of 6-factorial PMF, primary organic aerosol (POA) is estimated as

$\mathrm{POA}=\mathrm{HOA}+$ wood burning + charbroiling + minor source $(10)$

Then, a ratio of $15.9 \mu \mathrm{g} \mathrm{m}^{-3} / \mathrm{ppmv}\left( \pm 2.3 \mu \mathrm{g} \mathrm{m}^{-3} / \mathrm{ppmv}\right)$ for $\mathrm{HOA} / \mathrm{NO}_{\mathrm{x}}$ results for this campaign. Similar values can be calculated from a tunnel study (Kirchstetter et al., 1999): a ratio of $16 \mu \mathrm{g} \mathrm{m}^{-3} / \mathrm{ppmv}$ for diesel trucks and $11 \mu \mathrm{g} \mathrm{m}^{-3} / \mathrm{ppmv}$ for light-duty vehicles. In this calculation, HOA as the primary component from traffic emission was chosen. The emission ratios calculated for the morning hours of weekends (Saturdays, Sunday and 1 August) as well as of working days (Monday to Friday) do not significantly differ from the overall ratio of $15.9 \mu \mathrm{g} \mathrm{m}^{-3} / \mathrm{ppmv}$. On the other hand, values for after-noon and evening hours (12:0023:50 p.m.) are significantly larger $\left(s=27.7 \mu \mathrm{g} \mathrm{m}^{-3} / \mathrm{ppmv}\right)$. 
Table 3. Two different uncertainty estimates of the scores (or calculated source activities) for the $p=6$ factor solution (in \%): variability from different factorial approaches (var. in $p-1, p, p+1)$ and calculated 95\%-confidence intervals for the source contributions (est. 95\%-c.i. $\left.b_{k} \boldsymbol{g}_{i k}\right)$.

\begin{tabular}{lllllll}
\hline & OOA, type I & OOA, type II & HOA & charbroiling & wood & minor \\
\hline var. in $p-1, p, p+1$ & $39.8 \%-50.0 \%$ & $18.9 \%-22.3 \%$ & $6.3 \%-7.3 \%$ & $10.1 \%-14.7 \%$ & $7.4 \%-10.0 \%$ & $5.5 \%-6.5 \%$ \\
est. 95\%-c.i. $b_{k} \boldsymbol{g}_{i k}$ & $40.6 \%-49.0 \%$ & $21.7 \%-22.0 \%$ & $5.6 \%-8.6 \%$ & $10.1 \%-11.1 \%$ & $8.4 \%-10.3 \%$ & $5.2 \%-7.4 \%$ \\
average & $44.1 \%$ & $21.9 \%$ & $7.3 \%$ & $10.7 \%$ & $9.5 \%$ & $6.5 \%$ \\
\hline
\end{tabular}

Note that emission ratios calculated from ambient data that include $\mathrm{NO}_{\mathrm{x}}$ are uncertain due to $\mathrm{NO}_{2}$ reactivity.

For POA/EC a ratio of $1.1 \mu \mathrm{g} \mathrm{m}^{-3} / \mu \mathrm{gC} \quad( \pm 0.1$ $\left.\mu \mathrm{g} \mathrm{m}^{-3} / \mu \mathrm{gC}\right)-$ or $1.6 \mu \mathrm{g} \mathrm{m}^{-3} / \mu \mathrm{gC}\left( \pm 0.1 \mu \mathrm{g} \mathrm{m}^{-3} / \mu \mathrm{gC}\right)$ assuming an intercept of zero - is obtained. These values are similar to $1.4 \mu \mathrm{g} \mathrm{m}^{-3} / \mu \mathrm{gC}$ calculated from a dispersion modelling study for Northeastern United States by $\mathrm{Yu}$ et al. (2004). In Pittsburgh, a ratio of $1.4 \mu \mathrm{g} \mathrm{m}^{-3} / \mu \mathrm{gC}$ results from multivariate analysis of AMS data by Zhang et al. (2005b) and $1.2 \mu \mathrm{g} \mathrm{m}^{-3} / \mu \mathrm{gC}$ can be deduced from emission inventories (Cabada et al., 2002).

A ratio of $10.4 \mu \mathrm{g} \mathrm{m}^{-3} / \mathrm{ppmv}\left( \pm 0.4 \mu \mathrm{g} \mathrm{m}^{-3} / \mathrm{ppmv}\right)$ is found for POA/CO in Zurich in summer 2005. Very similar ratios resulted in Northeastern U.S. $\left(9.4 \mu \mathrm{g} \mathrm{m}^{-3} / \mathrm{ppmv}\right)$ calculated from various gaseous organics (de Gouw et al., $2005)$ as well as in Tokyo $\left(11 \mu \mathrm{g} \mathrm{m}^{-3} / \mathrm{ppmv}\right)$ based on AMS measurements (Takegawa et al., 2006).

In summary, these results support the interpretation of POA as given by Eq. (10) and further evidence is given that HOA can be related to traffic.

\subsection{Uncertainty estimates of source contributions}

The uncertainty of the source contributions as defined in Eq. (5) is a function of both, the uncertainty of the fitting parameter $b, \sigma\left(b_{k}\right)$, and the uncertainty of the scores $\sigma\left(\boldsymbol{g}_{i k}\right)$ :

$\sigma\left(b_{k} \boldsymbol{g}_{i k}\right)=f\left(\sigma\left(b_{k}\right), \sigma\left(\boldsymbol{g}_{i k}\right)\right)$

The uncertainties of the scores, $\sigma\left(\boldsymbol{g}_{i k}\right)$ (or G_std-dev in PMF2), depend on the uncertainty of $F$ (as $\mathbf{G}$ and $\mathbf{F}$ are not independent of each other). Unfortunately, the standard deviation of $\mathbf{G}$ is determined by the assumption that $\mathbf{F}$ is kept fix within PMF2 (Paatero, 2000). Rotational ambiguity is also contributing to total uncertainty; this is not taken into account by uncertainty calculations within PMF2, too. In practice, additional uncertainty comes also from the ambiguity in choosing the reduced dimensionality $p$.

Both the uncertainty (estimated 95\%-confidence interval) propagation according to Eq. (11) for the 6-factorial solution as well as ambiguity from choosing the 5-, 6-, or 7-factorial approach are summarized in Table 3 (values are given as percentages): these two ranges are in good agreement. Both suggest that the uncertainty in OOA, type II (volatile frac- tion) is rather small (18.9\%-22.3\% and $21.7 \%-22.0 \%)$, compared to OOA, type I (aged fraction) $(\sim 40 \%-50 \%)$. This is a hint that OOA, type II is strongly associated with a physical process (condensation at low temperatures at night) rather than a factor summarizing all kind of photochemical processes where a large number of VOC and OVOC precursors are involved (OOA, type I). The estimated 95\%-confidence intervals, $\left[\mu\left(b_{k} \boldsymbol{g}_{i k}\right) \pm 2 \sigma\left(b_{k} \boldsymbol{g}_{i k}\right)\right]$, of several primary components and sources overlap (Table 3 ). Nevertheless, we can state that charbroiling contributes significantly more to measured organics than HOA or aerosols from a minor source (influenced by food cooking).

\section{Conclusions}

PMF was successfully applied for the first time to organic aerosol mass spectra measured by an Aerodyne AMS. Up to six factors could be interpreted either as different sources or aerosol components contributing to the submicron organic aerosol (OA) in summer at Zurich-Kaserne, an urban background location in Switzerland. The average OA concentration was $6.58 \mu \mathrm{g} \mathrm{m}^{-3}$ or $66 \%$ of the total aerosol concentration measured by the AMS. In the 2-factorial solution, more than $85 \%$ of the organic aerosol was assigned to oxygenated organic aerosol (OOA-like factor).

When using more than two factors, the OOA-like factor accounts for around $60-69 \%$ of the total organic mass. In the 6-factorial PMF, OOA could be split into an aged, less volatile, fulvic acid-like (OOA, type I) and a volatile, highly temperature dependent, oxygenated organic aerosol fraction (OOA, type II). Within the primary organic aerosol (POA) classes, an average of 6-10\% hydrocarbon-like organic aerosols (HOA) (3- to 7-factorial PMF solutions) seems surprisingly small while charbroiling and wood burning (both at $\sim 10 \%$ ) exceeded the estimated aerosol concentration from incomplete fossil fuel combustion. The calculated contribution of wood burning is in good agreement with results based on ${ }^{14} \mathrm{C}$ analyses (Szidat et al., 2006). A source potentially interpreted as food cooking makes up $6 \%$ of the total organics. Our results indicate that organic aerosols in Zurich in summer are composed of one third from primary and two thirds from secondary origins. These findings are in 
line with the studies from Pittsburgh (Zhang et al., 2005b) as well as Mexico City (Volkamer et al., 2006).

Since there are significant primary emissions of oxygenated compounds in Zürich ( $\sim 24-27 \%)$ the 2-factorial approaches overestimate the contribution of SOA by about 15$25 \%$ if the OOA-like factor is interpreted as secondary organic aerosol (SOA). Note that those two PMF factors show good agreement with measured spectra representing OOA and HOA (Alfarra, 2004; Zhang et al., 2005a), the 2-factorial solution is associated with lowest rotational freedom and explains virtually all variance of the time series of total AMSorganics. However, the OOA- and HOA-like factors from 2factorial PMF should not be equated to SOA and POA as the direct emission of oxygenated aerosol species from sources like biomass burning, charbroiling, food cooking etc. cannot be ruled out. It was shown e.g. by Simoneit et al. (1993) that emissions of those sources can include a myriad of oxidized organic compounds. The sum of (OOA, type I) and (OOA, type II) might represent SOA but we cannot rule out that oxidized primary particle emissions contribute to OOA in the mass spectrum. Primary biogenic emissions (e.g. wax fragments) could also be significant sources of OOA, although no indication was found in this study. In addition, Zurich-Kaserne might be slightly biased toward charbroiling and wood burning particles because of some local emission events. Thus, further application of this method to other datasets will give more insight into the variability of the source composition at different locations.

Acknowledgements. The AMS measurements were supported by the Swiss Federal Office for the Environment (FOEN). The measurement trailer was provided by the Kanton Zürich. We thank U. Lohmann, J. Staehelin, H. Coe, P. Paatero, and two anonymous reviewers for valuable comments and suggestions which significantly improved this paper. Helpful reference spectra from C. Marcolli and A. M. Middlebrook, as well as from S. Weimer and J. Schneider are greatly appreciated. We also thank J. Allan for providing his IGOR codes, as well as J.-L. Jimenez, Q. Zhang, M. Canagaratna, I. Ulbrich, and D. R. Worsnop for critical comments.

Edited by: T. Koop

\section{References}

Alfarra, M. R.: Insights into Atmospheric Organic Aerosols Using an Aerosol Mass Spectrometer, Ph.D. thesis, University of Manchester Institute of Science and Technology (UMIS), Manchester, 2004.

Alfarra, M. R., Coe, H., Allan, J. D., Bower, K. N., Boudries, H., Canagaratna, M. R., Jimenez, J. L., Jayne, J. T., Garforth, A., Li, S.-M., and Worsnop, D. R.: Characterization of urban and regional organic aerosols in the lower Fraser Valley using two Aerodyne Aerosol Mass Spectrometers, Atmos. Environ., 38, 5745-5758, 2004.

Alfarra, M. R., Paulsen, D., Gysel, M., Garforth, A. A., Dommen, J., Prévôt, A. S. H., Worsnop, D. R., Baltensperger, U., and Coe,
H.: A mass spectrometric study of secondary organic aerosols formed from the photooxidation of anthropogenic and biogenic precursors in a reaction chamber, Atmos. Chem. Phys., 6, 52795293, 2006a.

Allan, J. D., Jimenez, J. L., Williams, P. I., Alfarra, M. R., Bower, K. N., Jayne, J. T., Coe, H., and Worsnop, D. R.: Quantitative sampling using an Aerodyne aerosol mass spectrometer 1. Techniques of data interpretation and error analysis, J. Geophys. Res.-Atmos., 108(D3), 4090, doi:10.1029/2002JD002358, 2003.

Allan, J. D., Delia, A. E., Coe, H., Bower, K. N., Alfarra, M. R., Jimenez, J. L., Middlebrook, A. M., Drewnick, F., Onasch, T. B., Canagaratna, M. R., Jayne, J. T., and Worsnop, D. R.: A generalised method for the extraction of chemically resolved mass spectra from aerodyne aerosol mass spectrometer data, J. Aerosol Sci., 35, 909-922, 2004.

Bahreini, R., Keywood, M., Ng, N. L., Varutbangkul, V., Gao, S., Flagan, R. C., Seinfeld, J. H., Worsnop, D. R., and Jimenez, J. L.: Measurements of secondary organic aerosol from oxidation of cycloalkanes, terpenes, and m-xylene using the Aerodyne Aerosol Mass Spectrometer, Environ. Sci. Technol., 39, 56745688, 2005.

Begum, B. A., Kim, E., Biswas, S. K., and Hopke, P. K.: Investigation of sources of atmospheric aerosol at urban and semi-urban areas in Bangladesh, Atmos. Environ., 38, 3025-3038, 2004.

Buset, K. C., Evans, G. J., Leaitch, W. R., Brook, J. R., and ToomSauntry, D.: Use of advanced receptor modelling for analysis of an intensive 5-week aerosol sampling campaign, Atmos. Environ., 40, Suppl. 2, 482-499, 2006.

Cabada, J. C., Pandis, S. N., and Robinson, A. L.: Sources of atmospheric carbonaceous particulate matter in Pittsburgh, Pennsylvania, J. Air Waste Manag. Assoc., 52(6), 732-741, 2002.

Cabada, J. C., Pandis, S. N., Subramanian, R., Robinson, A. L., Polidori, A., and Turpin, B.: Estimating the secondary organic aerosol contribution to PM2.5 using the EC tracer method, Aerosol Sci. Technol., 38, Suppl. 1, 140-155, 2004.

Canagaratna, M. R., Jayne, J. T., Ghertner, D. A., Herndon, S., Shi, Q., Jimenez, J. L., Silva, P. J., Williams, P., Lanni, T., Drewnick, F., Demerjian, K. L., Kolb, C. E., and Worsnop, D. R.: Chase studies of particulate emissions from in-use New York city vehicles, Aerosol Sci. Technol., 38, 555-573, doi:10.1080/02786820490465504, 2004.

Chung, Y. S., Kim, S. H., Moon, J. H., Kim, Y. J., Lim, J. M., and Lee, J. H.: Source identification and long-term monitoring of airborne particulate matter PM2.5/PM10) in an urban region of Korea, J. Radioanal. Nucl. Chem., 267, 35-48, 2005.

de Gouw, J. A., Middlebrook, A. M., Warneke, C., Goldan, P. D., Kuster, W. C., Roberts, J. M., Fehsenfeld, F. C., Worsnop, D. R., Canagaratna, M. R., Pszenny, A. A. P., Keene, W. C., Marchewka, M., Bertman, S. B., and Bates, T. S.: Budget of organic carbon in a polluted atmosphere: Results from the New England Air Quality Study in 2002, J. Geophys. Res.-Atmos., 110, D16305, doi:10.1029/2004JD005623, 2005.

EKL: Status-Bericht der Eidg. Kommission für Lufthygiene. Stickstoffhaltige Luftschadstoffe in der Schweiz, Schriftenreihe Umwelt Nr. 384, Herausgegeben vom Bundesamt für Umwelt, Wald und Landschaft BUWAL, Bern, 2005.

Empa: Technischer Bericht zum Nationalen Beobachtungsnetz für Luftfremdstoffe (NABEL), available at: http://www.empa.ch/ 
nabel, Dübendorf, Switzerland, 2005.

Fuzzi, S., Andreae, M. O., Huebert, B. J., Kulmala, M., Bond, T. C., Boy, M., Doherty, S. J., Guenther, A., Kanakidou, M., Kawamura, K., Kerminen, V.-M., Lohmann, U., Russell, L. M., and Pschl, U.: Critical assessment of the current state of scientific knowledge, terminology, and research needs concerning the role of organic aerosols in the atmosphere, climate, and global change, Atmos. Chem. Phys., 6, 2017-2038, 2006, http://www.atmos-chem-phys.net/6/2017/2006/.

Hedberg, E., Gidhagen, L., and Johansson, C.: Source contributions to PM10 and arsenic concentrations in Central Chile using positive matrix factorization, Atmos. Environ., 39, 549-561, 2005.

Hien, P. D., Bac, V. T., and Thinh, N. T. H.: PMF receptor modelling of fine and coarse PM10 in air masses governing monsoon conditions in Hanoi, Northern Vietnam, Atmos. Environ., 38, 189-201, 2004.

Hopke, P. K: Recent developments in receptor modeling, J. Chemom., 17, 255-265, 2003.

Huang, S., Rahn, K. A., and Arimoto, R.: Testing and optimizing two factor-analysis techniques on aerosol at Narragansett, Rhode Island, Atmos. Environ., 33, 2169-2185, 1999.

Horvath, H.: Atmospheric light-absorption - A review, Atmos. Environ. Part A-General Topics, 27, 293-317, 1993.

Jaffrezo, J.-L., Aymoz, G., and Cozic, J.: Size distribution of EC and $\mathrm{OC}$ in the aerosol of Alpine valleys during summer and winter, Atmos. Chem. Phys., 5, 2915-2925, 2005, http://www.atmos-chem-phys.net/5/2915/2005/.

Jayne, J. T., Leard, D. C., Zhang, X. F., Davidovits, P., Smith, K. A., Kolb, C. E., and Worsnop, D. R.: Development of an aerosol mass spectrometer for size and composition analysis of submicron particles, Aerosol Sci. Technol., 33, 49-70, 2000.

Jenkin, M. E., Saunders, S. M., Wagner, V., and Pilling, M. J.: Protocol for the development of the Master Chemical Mechanism, MCM v3 (Part B): tropospheric degradation of aromatic volatile organic compounds, Atmos. Chem. Phys., 3, 181-193, 2003, http://www.atmos-chem-phys.net/3/181/2003/.

Jimenez, J.-L., Jayne, J. T., Shi, Q., Kolb, C. E., Worsnop, D. R., Yourshaw, I., Seinfeld, J. H., Flagan, R. C., Zhang, X. F., Smith, K. A., Morris, J. W., and Davidovits, P.: Ambient aerosol sampling using the Aerodyne Aerosol Mass Spectrometer, 108(D7), 8425, doi:10.1029/2001JD001213, 2003.

Kalberer, M., Paulsen, D., Sax, M., Steinbacher, M., Dommen, J., Prevot, A. S. H., Fisseha, R., Weingartner, E., Frankevich, V., Zenobi, R., and Baltensperger, U.: Identification of polymers as major components of atmospheric organic aerosols, Science, 303, 1659-1662, 2004.

Kanakidou, M., Seinfeld, J. H., Pandis, S. N., Barnes, I., Dentener, F. J., Facchini, M. C., van Dingenen, R., Ervens, B., Nenes, A., Nielsen, C. J., Swietlicki, E., Putaud, J. P., Balkanski, Y., Fuzzi, S., Horth, J., Moortgat, G. K., Winterhalter, R., Myhre, C. E. L., Tsigaridis, K., Vignati, E., Stephanou, E. G., and Wilson, J.: Organic aerosol and global climate modelling: a review, Atmos. Chem. Phys., 5, 1053-1123, 2005,

http://www.atmos-chem-phys.net/5/1053/2005/.

Katrib, Y., Martin, S. T., Hung, H. M., Rudich, Y., Zhang, H. Z., Slowik, J. G., Davidovits, P., Jayne, J. T., and Worsnop, D. R.: Products and mechanisms of ozone reactions with oleic acid for aerosol particles having core-shell morphologies, J. Phys. Chem., A 108, 6686-6695, 2004.
Kim, E., Hopke, P. K., and Edgerton, E. S.: Source identification of Atlanta aerosol by positive matrix factorization, J Air Waste Manage. Assoc., 53, 731-739, 2003.

Kim, E. and Hopke, P. K.: Identification of fine particle sources in mid-Atlantic US area, Water Air Soil Pollut., 168, 391-421, 2005.

Kirchstetter, T., Harley, R., Kreisberg, N., Stolzenburg, M., and Hering, S.: On-road measurement of fine particle and nitrogen oxide emissions from light- and heavy-duty motor vehicles, Atmos. Environ., 33(18), 2955-2968, 1999.

Lee, E., Chun, C. K., and Paatero, P.: Application of Positive Matrix Factorization in Source Apportionment of Particulate Pollutants, Atmos. Environ., 33, 3201-3212, 1999.

Li, Z., Hopke, P. K., Husain, L., Qureshi, S., Dutkiewicz, V. A., Schwab, J. J., Drewnick, F., and Demerjian, K. L.: Sources of fine particle composition in New York city, edited by: Li, Z., Hopke, P. K., and Husain, L., Atmos. Environ., 38, 6521-6529, 2004.

Liu, W., Hopke, P. K., and VanCuren, R. A.: Origins of fine aerosol mass in the western United States using positive matrix factorization, J. Geophys. Res.-Atmos., 108(D23), 4716, doi:10.1029/2003JD003678, 2003.

Lohmann, U. and Feichter, J.: Global indirect aerosol effects: a review, Atmos. Chem. Phys., 5, 715-737, 2005, http://www.atmos-chem-phys.net/5/715/2005/.

Nel, A.: Air pollution-related illness: effects of particles, Science, 308, 804-806, 2005.

NIST: National Institute of Standards and Technology, NIST Chemistry WebBook, available at: http://webbook.nist.gov/chemistry, July 2006.

Paatero, P.: Least squares formulation of robust non-negative factor analysis, Chemom. Intell. Lab. Syst., 37, 23-35, 1997.

Paatero, P.: User's guide for positive matrix factorization programs PMF2.EXE and PMF3.EXE, University of Helsinki, Finland, 2000.

Paatero, P: User's guide for positive matrix factorization programs PMF2 and PMF3, part 1: tutorial, University of Helsinki, Finland, 2007.

Paatero, P. and Tapper, U.: Positive matrix factorization: a nonnegative factor model with optimal utilization of error estimates of data values, Environmetrics, 5, 111-126, 1994.

Pekney, N. J., Davidson, C. I., Robinson, A., Zhou, L., Hopke, P., Eatough, D., and Rogge, W. F.: Major source categories for PM2.5 in Pittsburgh using PMF and UNMIX, Aerosol Sci. Technol., 40, 910-924, 2006.

Quinn, P. K., Bates, T. S., Coffman, D., Onasch, T. B., Worsnop, D., Baynard, T., de Gouw, J. A., Goldan, P. D., Kuster, W. C., Williams, E., Roberts, J. M., Lerner, B., Stohl, A., Pettersson, A., and Lovejoy, E. R.: Impacts of sources and aging on submicrometer aerosol properties in the marine boundary layer across the Gulf of Maine, J. Geophys. Res., 111, D23S36, doi:10.1029/2006JD007582, 2006.

Ramadan, Z., Song, X. H., and Hopke, P. K.: Identification of sources of Phoenix aerosol by positive matrix factorization, J. Air Waste Manage. Assoc., 50, 1308-1320, 2000.

Schauer, J. J., Rogge, W. F., Hildemann, L. M., Mazurek, M. A., Cass, G. R., and Simoneit, B. R. T.: Source apportionment of airborne particulate matter using organic compounds as tracers, Atmos. Environ., 30, 3837-3855, 1996. 
Schauer, J. J., Kleeman, M. J., Cass, G. R., and Simoneit, B. R. T.: Measurement of emissions from air pollution sources. 1. C1 through C29 organic compounds from meat charbroiling, Environ. Sci. Technol., 33, 1566-1577, 1999.

Schneider, J., Weimer, S., Drewnick, F., Borrmann, S., Helas, G., Gwaze, P., Schmid, O., Andreae, M. O., and Kirchner, U.: Mass spectrometric analysis and aerodynamic properties of various types of combustion-related aerosol particles, Int. J. Mass. Spec., 258, 37-49, 2006.

Simoneit, B. R. T., Rogge, W. F., Mazurek, M. A., Standley, L. J., Hildemann, L. M., and Cass, G. R.: Lignin pyrolysis products, lignans, and resin acids as specific tracers from biomass combustion, Environ. Sci. Technol., 27, 2533-2540, 1993.

Song, X. H., Polissar, A. V., and Hopke, P. K.: Sources of fine particle composition in the northeastern US, Atmos. Environ., 35, 5277-5286, 2001.

Steinbacher, M., Zellweger, C., and Schwarzenbach, B.: Nitrogen oxides measurements at rural sites in Switzerland: bias of conventional measurement techniques, J. Geophys. Res., accepted, 2007.

Szidat, S., Jenk, T. M., Synal, H.-A., Kalberer, M., Wacker, L., Hajdas, I., Kasper-Giebl, A., and Baltensperger, U.: Contributions of fossil fuel, biomass-burning, and biogenic emissions to carbonaceous aerosols in Zurich as traced by 14C, J. Geophys. Res., 111, D07206, doi:10.1029/2005JD006590, 2006.

Takegawa, N., Miyakawa, T., Kondo, Y., Jimenez, J. L., Zhang, Q., Worsnop, D. R., and Fukuda, M.: Seasonal and diurnal variations of submicron organic aerosol in Tokyo observed using the Aerodyne aerosol mass spectrometer, J. Geophys. Res., 111, D11206, doi:10.1029/2005JD006515, 2006.
Turpin, B. J. and Huntzicker, J. J.: Identification of secondary organic aerosol episodes and quantification of primary and secondary organic aerosol concentrations during SCAQS, Atmos. Environ., 29, 3527-3544, 1995.

Volkamer, R., Jimenez, J. L., San Martini, F., Dzepina, K., Zhang, Q., Salcedo, D., Molina, L. T., Worsnop, D. R., and Molina, M. J.: Secondary organic aerosol formation from anthropogenic air pollution: rapid and higher than expected, Geophys. Res. Lett., 33, L17811, doi:10.1029/2006GL026899, 2006.

Yu, S., Dennis, R. L., Bhave, P. V., and Eder, B. K.: Primary and secondary organic aerosols over the United States: estimates on the basis of observed organic carbon (OC) and elemental carbon (EC), and air quality modeled primary OC/EC ratios, Atmos. Environ., 38(31), 5257-5268, 2004.

Yuan, Z. B., Lau, A. K. H., Zhang, H. Y., Yu, J. Z., Louie, P. K. K., and Fung, J. C. H.: Identification and spatiotemporal variations of dominant PM10 sources over Hong Kong, Atmos. Environ., 40, 1803-1815, 2006.

Zhang, Q., Alfarra, M. R., Worsnop, D. R., Allan, J. D., Coe, H., Canagaratna, M. R., and Jimenez, J. L.: Deconvolution and quantification of hydrocarbon-like and oxygenated organic aerosols based on aerosol mass spectrometry, Environ. Sci. Technol., 39, 4938-4952, 2005a.

Zhang, Q., Worsnop, D. R., Canagaratna, M. R., and Jimenez, J. L.: Hydrocarbon-like and oxygenated organic aerosols in Pittsburgh: insights into sources and processes of organic aerosols, Atmos. Chem. Phys., 5, 3289-3311, 2005b.

Zhao, W. X. and Hopke, P. K.: Source identification for fine aerosols in Mammoth Cave National Park, Atmos. Res., 80, 309322, 2006. 